University of Louisville

ThinkIR: The University of Louisville's Institutional Repository

\title{
The trends and disparities in the diagnosis of breast cancer by mobile mammography at a comprehensive cancer center.
}

Dianhong Luo

University of Louisville

Follow this and additional works at: https://ir.library.louisville.edu/etd

\section{Recommended Citation}

Luo, Dianhong, "The trends and disparities in the diagnosis of breast cancer by mobile mammography at a comprehensive cancer center." (2012). Electronic Theses and Dissertations. Paper 867.

https://doi.org/10.18297/etd/867

This Master's Thesis is brought to you for free and open access by ThinkIR: The University of Louisville's Institutional Repository. It has been accepted for inclusion in Electronic Theses and Dissertations by an authorized administrator of ThinkIR: The University of Louisville's Institutional Repository. This title appears here courtesy of the author, who has retained all other copyrights. For more information, please contact thinkir@louisville.edu. 


\title{
THE TRENDS AND DISPARITIES IN THE DIAGNOSIS OF BREAST CANCER BY MOBILE MAMMOGRAPHY AT A COMPREHENSIVE CANCER CENTER
}

\author{
By \\ Dianhong Luo

\begin{abstract}
A Thesis
Submitted to the Faculty of the

School of Public Health and Information Sciences of the University of Louisville

In Partial Fulfillment of the Requirements

For the Degree of
\end{abstract} \\ Master of Science \\ Department of Bioinformatics and Biostatistics \\ University of Louisville \\ Louisville, Kentucky \\ August 2012
}




\section{Copyright 2012 by Dianhong Luo}

All rights reserved 
THE TRENDS AND DISPARITIES IN THE DIAGNOSIS OF BREAST CANCER BY MOBILE MAMMOGRAPHY AT A COMPREHENSIVE CANCER CENTER By

Dianhong Luo

A Thesis Approved on

April 19, 2012

By the following Thesis Committee:

Dr. Dongfeng Wu

Thesis Director

Dr. Anthony Dragun

Dr. Shesh Rai

Dr. Seongho Kim 


\section{DEDICATION}

This thesis is dedicated to my beloved family 


\section{ACKNOWLEDGMENTS}

I would like to express my deepest appreciation to Dr. Dongfeng Wu for her guidance, encouragement and reassurance. I would also like to thank the other committee members, Dr. Shesh Rai, Dr. Seongho Kim, and Dr. Anthony Dragun for their comments and assistance.

Special thanks are given to Laura Fry, Dr. Sarah Mizuguchi, Dr. Laura Barkley and Dr. Lane Roland for their hard work of data collection and organization; Dr. Robert J. Esterhay for his valuable suggestions of data analysis.

Other thanks are given to Jason Perkins of University Hospital Brown Cancer Center for his technical support. 


\begin{abstract}
THE TRENDS AND DISPARITIES IN THE DIAGNOSIS OF BREAST CANCER BY MOBILE MAMMOGRAPHY AT A COMPREHENSIVE CANCER CENTER
\end{abstract}

Dianhong Luo

April 5, 2012

This study used the de-identified breast cancer screen data which recorded the information of 58231 screens and 22534 participants with different background. The analysis of disparities on age, ethnic, health insurance and screen location has been done based on screen and participant number. Women younger than 50 or white, or the women without insurance are most likely to take the screen. The percentages are $40 \%, 64 \%$ and $40 \%$ under each category. The most popular location for screen is partnership clinic, which comprise $43 \%$ of screens. The year 2006 has the most screens which is 6861 , and 2001 has the least which is 4813 . The trend over the years and the disparities of pathology results were assessed. Chi-square test was performed to check the association. The odds ratios based on participants number are calculated. For race/insurance, in age groups "50-", "50-59" and "70+", the odds of white people with insurance is about 1.7, 1.9 and 0.4 of black people with insurance. No difference was found in age group "60-69". For race/pathology result, the significant result is only for age group " $70+$ ", and the odds of white women with "Negative" pathology result is 4.4 times of black women with "Negative" pathology result. Besides, for insurance/pathology result, the odds of women with insurance "Yes" having "Negative" pathology result are 2.26 and 2.08 times of the 
women with insurance "Yes" having "Negative" pathology result for age group "50-" and " $50-59$ ". The follow-up study was presented in this thesis. The maximum number that each person took the screen is 17 . The majority (45\%) only take screen once. About $19 \%$ of women take twice, $12 \%$ take triple. Only 1 woman takes 17 times. Pearson and Spearman correlation coefficients were calculated to check the association. 


\section{TABLE OF CONTENTS}

\section{PAGE}

ACKNOWLEDGMENTS .................................................... iv

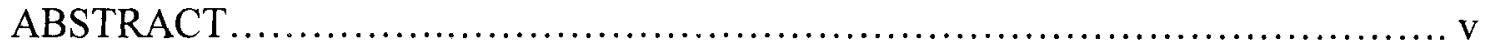

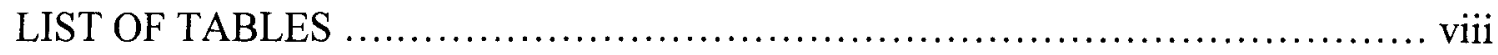

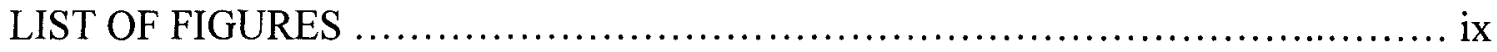

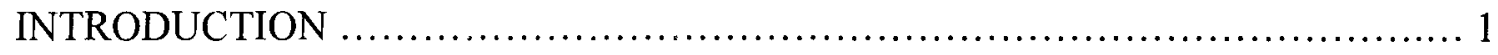

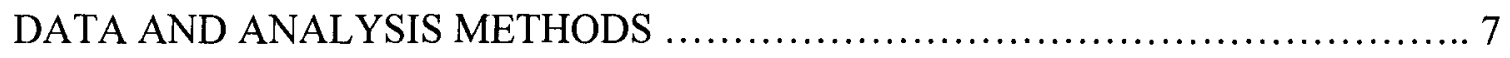

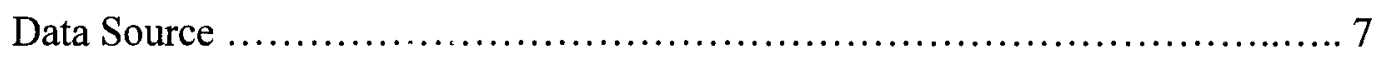

Analysis methods ...................................................... 9

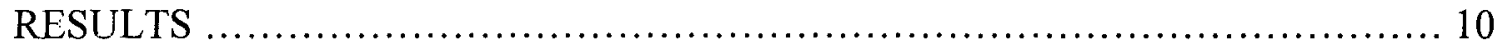

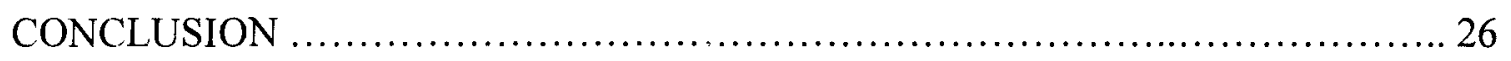

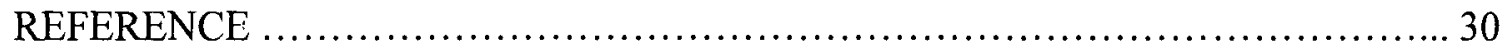

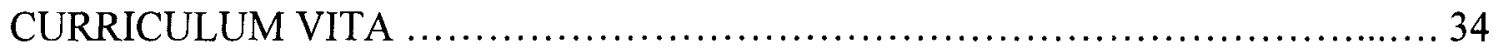




\section{LIST OF TABLES}

TABLE

PAGE

1. Summary of De-identified breast cancer screen data $\ldots \ldots \ldots \ldots \ldots \ldots \ldots \ldots \ldots . \ldots$

2. Proportion of Participants in the breast cancer screens $\ldots \ldots \ldots \ldots \ldots \ldots \ldots \ldots \ldots \ldots 11$

3. Pathology result based on age group/race/insured $\ldots \ldots \ldots \ldots \ldots \ldots \ldots \ldots \ldots \ldots \ldots$

4. Summary of patients of De-identified breast cancer screen data ................ 19

5. Odds ratio of Race/Insurance for different age group ........................ 20

6. Odds ratio of Race/pathology result for different age group $\ldots \ldots \ldots \ldots \ldots \ldots \ldots \ldots .1$

7. Odds ratio of Insurance/Pathology result for different age group $\ldots \ldots \ldots \ldots \ldots \ldots 22$

8. Summary of screen numbers for each age group/race/insured $\ldots \ldots \ldots \ldots \ldots \ldots \ldots . \ldots 24$

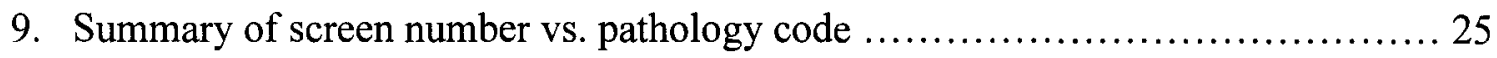

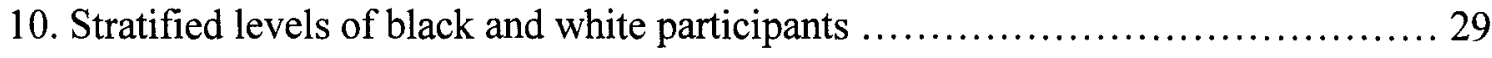




\section{LIST OF FIGURES}

FIGURE

PAGE

1. Screen frequency of agegroup over 10 year for race=black $\ldots \ldots \ldots \ldots \ldots \ldots \ldots \ldots \ldots 12$

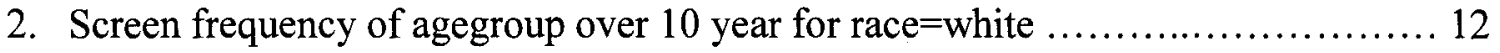

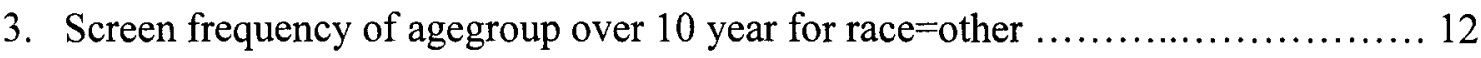

4. Screen frequency of agegroup over 10 year for insured=private Insured .......... 13

5. Screen frequency of agegroup over 10 year for insured=public Insured ........... 13

6. Screen frequency of agegroup over 10 year for insured=uninsured $\ldots \ldots \ldots \ldots \ldots \ldots 14$

7. Screen frequency of agegroup over 10 year for location=corporate ............... 14

8. Screen frequency of agegroup over 10 year for location=partnership clinic $\ldots \ldots \ldots 15$

9. Screen frequency of agegroup over 10 year for location=partnership community... 15

10. Trend of screen disparities on age group of each race at code $=0 \ldots \ldots \ldots \ldots \ldots \ldots 17$

11. Trend of screen disparities on age group of each race at code $=6 \ldots \ldots \ldots \ldots \ldots \ldots 17$

12. Trend of screen disparities on age group of each insurance at code $=0 \ldots \ldots \ldots \ldots 18$

13. Trend of screen disparities on age group of each insurance at code $=6 \ldots \ldots \ldots \ldots 18$ 


\section{CHAPTER I}

\section{INTRODUCTION}

Breast cancer is the most common cancer among American women, except for skin cancers. The chance of developing invasive breast cancer at some time in a woman's life is a little less than 1 in $8(12 \%)$. The American Cancer Society's most recent estimates for breast cancer in the United States are for 2012 [1]:

- About 226,870 new cases of invasive breast cancer will be diagnosed in women.

- About 63,300 new cases of carcinoma in situ (CIS) will be diagnosed (CIS is non-invasive and is the earliest form of breast cancer).

- About 39,510 women will die from breast cancer

The risk for breast cancer increases with age and several other factors which include genetic history, obesity, not or late child bearing, early menarche, and late menopause [2]. The incidence of breast cancer (ductal carcinoma in situ (DCIS) and invasive breast cancer) has risen substantially over the past 20 years [3-4], in parallel with increasing use of screening mammography. But the female breast cancer incidence rates decreased by about $2 \%$ per year from 1999 to 2005 . This decrease was seen only in women aged 50 or older, and may be due at least in part to the decline in use of hormone therapy after menopause.

Breast cancer is also the second leading cause of cancer death in women, exceeded only by lung cancer. The chance that breast cancer will be responsible for a 
woman's death is about 1 in 36 (about 3\%). Death rates from breast cancer have been declining since about 1990, with larger decreases in women younger than 50 . These decreases are believed to be the result of earlier detection through screening and increased awareness, as well as improved treatment.

Cancer-related organizations such as the American Medical Association, the American College of Obstetricians and Gynecologists (ACOG), and the American Cancer Society recommend that women age 40 and older have a mammogram every year. The Health People 2010 (HP2010) planed to have 70\% of women over 40 years old with mammogram. But some states have not achieved the objective [5]. The breast cancer screening rate has been increasing steadily since the 1990s but fell slightly between 1999 and 2002 [6]. This drop in the screening rate raised the concern that breast cancer occurrence and mortality rates might increase. Moreover, despite the overall increase in the screening rate, disparities based on race, age, education, income or social class still exist in breast cancer screening [7-10]. Understanding the strong association between demographic position and the breast cancer screening rate may provide insight into improving the screening rate.

Several studies in other countries have revealed disparities between population subgroups at each phase of breast cancer [11-13]. Although disparities in screening mammography have improved overall since the early 1990s, significant differences in screening persist among many medically underserved communities. Vulnerable populations such as racial/ethnic minorities, the elderly, and the poor are more likely to be uninsured and lack a usual source of care. Compared to their middle-class and wealthy counterparts, low-income women have the lowest rates of breast cancer screening, even 
when adjusted for race, ethnicity, and insurance status [14-16]. Low socioeconomic status (SES) is a consistent marker for mammography underuse;

All racial/ethnic minorities in the U.S. have been documented underutilization of preventive health services that reflect sociodemographic variables, cultural barriers, and health systems obstacles. National Health Interview Survey (NHIS) describes new immigrants as the latest subpopulation of women with low rates of mammography use. Only $39.3 \%$ of women living in the U.S. for less than 10 years reported having a mammogram within the prior 2 years, in comparison to $64.7 \%$ of women living in the U.S. for 10 years or more and $71.3 \%$ of women born in the U.S. [17] Immigrants are disproportionately members of racial/ethnic minorities, making these women at particularly high risk for underuse of mammography. Besides, the black women in USA receive less mammography than white women even with similar use of primary care. A study showed black women were more likely to not undergo mammography (odds ratio [OR], 3.00 [95\% CI, 2.41 to 3.75]) and to be given a diagnosis of late-stage disease (OR, 2.49 [CI, 1.59 to 3.92$])$ than white women [18]. Although some research suggests that this gap may be narrowing [19], the difference in use of mammography between black women and white women persists. Having a regular provider or source of health care is the most important determinant of mammography use [20-21]. Whites, younger women, and women with higher incomes and more education are consistently more likely to use mammography. Although the effect is more modest than that of the other factors, having insurance that covers the cost of mammography has been shown to increase the use of mammography. For both black and white women, greater mammography use was associated with more visits to a primary care physician. The deficit for black women 
persisted at each socioeconomic status, even after use of primary care was considered. The number of primary care visits did less to "boost" mammography use for black women than for white women. Thus, although the number of visits made to a primary care physician does influence mammography use, it is not sufficient to overcome socioeconomic and regional differences in mammography use. These results suggest that the nature of primary care may vary within and among states and between black women and white women.

Age is another cause of disparities in mammography. Women aged 65 years and older comprise only $14 \%$ of women in the United States, nearly half (47\%) of breast cancer cases diagnosed annually and more than half (53\%) of breast cancer mortality occurs in this age group [22-23]. Despite increased risk and evidence suggesting that mammography's mortality benefits can extend to elderly populations, older women are less likely to be screened [24-25]. There has been little research addressing whether mammography is effective in decreasing breast cancer mortality in these women. This is due, in part, to competing risks of death and limited life expectancy; although elderly women have the highest risk of breast cancer, they are actually more likely to die of cardiovascular disease than malignancy [26]. Conflicting recommendations by various organizations about the age to stop mammographic screening reflect the uncertainty about the benefits of screening mammography in older women [27-31]. Numerous studies verify that women age 70 and older have lower rates of mammography compared to those between 50 and 69 years of age [32-33].

Women who live in rural areas are the one of subgroups for under-screening. Previous studies have suggested that women living in rural areas of the United States may 
use preyentive health care services less frequently than women living in urban areas of the country [34]. Studies also have found that women living in rural areas are less likely than those living in urban areas to have had a recent mammogram or Papanicolau (Pap) test [35-36]. Furthermore, women in rural areas of the United States have been found to have higher rates of breast carcinoma and late-stage disease than women in non-rural areas [37]. Possible explanations to account for the less frequent use of preventive services by rural women, compared with non-rural women include they are more likely to be uninsured, have a low household income, and be less educated; they are at particular risk of preventive care underutilization compared to women in non-rural regions. A research showed [38] that women residing in rural areas of the US are screened for breast cancer at a significantly lower rate than women in urban areas (66.7\% vs. $75.4 \%)$. Many rural regions are characterized by longer distances between medical facilities and less availability of health services, subsequently limiting access to breast cancer screening [39]. In addition, studies suggest that screening disparities between rural and non-rural populations are more pronounced among minorities. For example, rural ethnic subgroups such as African-American and Native-American women have been found to receive less cancer screening than their non-rural counterparts [40].

The United States may be farther from its national goals of screening mammography, particularly among underserved women. Over the past two decades, health agencies on the federal and state level have made efforts to increase mammography use through outreach programs to those underserved women. The disparities of mammography screen have been improved, but the significant differences persist in the patterns of mammography by race /ethnicity, age, demographic, 
socioeconomic, and health system variables. The cause of breast cancer disparities is comprehensive. A study must define and character the groups that have fewer screening. Most previous studies have observed the differences among cross-sectional disparities factors. However, continued monitoring of population-based trends and variations in breast cancer screening use by demographic position is needed. This study assessed the difference in the breast cancer screen according to women vs. socioeconomic position and examined the trends in breast cancer screen by observing differences in age, health insurance system, and racial demographics over 10 years period. The study explores the various barriers to mammography, with special attention to the unique needs of different populations. Despite the heterogeneity of medically underserved women, many of the barriers are common to different populations and reflect limited access to health information and services. 


\section{CHAPTER II}

\section{DATA AND ANALYSIS METHODS}

\section{Data sources}

The De-identified breast cancer screen data were taken from 2001-2010 by James

Graham Brown Cancer Center. The subjects are civilian, non-institutionalized adults aged 18 older. The purpose is to find the trends and disparities of impact of mobile mammography on the diagnosis of breast cancer. The screen is performed at 236 locations in state of Kentucky. If any abnormal is found, a further exam like ultrasound or biopsy is performed. A total of 22534 women enter the program and some of them take multiple screens, so make a total of 58231 screens within 10 years.

The data set includes 14 variables that are patient study number, Corporate or Partnership Clinic or Partnership Community, Age, Comp date, Hispanic(Hispanic Y, N, Unknown), Ethnic, CPT, CPT name, Assessment, Rec Desc (description),Pathology, pathology code, Insured or uninsured, lost to F/U. The purpose of the thesis is to identify the disparities of people who participates the mammography screen based on race, age, insurance system and residual area. So we limit our analysis to those key variables such as location, age-group, ethnic, and insured.

Laura Fry and Dr. Sarah Mizuguchi classified the 236 screen locations into 3 categories under variable "location": Corporate, Partnership Clinic, and Partnership Community, and 25 insurance companies into 3 categories under variable "insured": Uninsured, Private insured and Public insured, which makes the job easier. The variable 
Table 1

$\underline{\text { Summary of De-identified breast cancer screen data }}$

\begin{tabular}{|c|c|c|c|}
\hline Variable & Value & $\begin{array}{r}\text { Frequency } \\
\text { Count }\end{array}$ & $\begin{array}{r}\text { Percent of Total } \\
\text { Frequency }\end{array}$ \\
\hline \multirow[t]{3}{*}{ Insured } & Uninsured & 22997 & 39.5532 \\
\hline & Private Insured & 21062 & 36.2251 \\
\hline & Public Insured & 14083 & 24.2217 \\
\hline \multirow[t]{3}{*}{ Location } & PARTNERSHIP CLINIC & 25284 & 43.4866 \\
\hline & CORPORATE & 19319 & 33.2273 \\
\hline & PARTNERSHIP COMMUNITY & 13539 & 23.2861 \\
\hline \multirow[t]{4}{*}{ agegroup } & $50-$ & 23073 & 39.6839 \\
\hline & $50-59$ & 19044 & 32.7543 \\
\hline & $60-69$ & 10291 & 17.6998 \\
\hline & $70+$ & 5734 & 9.8621 \\
\hline \multirow[t]{7}{*}{ Pathology code } & 0 & 57181 & 98.3472 \\
\hline & 1 & 506 & 0.8703 \\
\hline & 6 & 233 & 0.4007 \\
\hline & 2 & 157 & 0.2700 \\
\hline & 4 & 39 & 0.0671 \\
\hline & 3 & 22 & 0.0378 \\
\hline & 5 & 4 & 0.0069 \\
\hline \multirow[t]{3}{*}{ race } & White & 37104 & 63.8162 \\
\hline & Black & 16252 & 27.9523 \\
\hline & Other & 4786 & 8.2316 \\
\hline \multirow[t]{10}{*}{ year } & 2006 & 6861 & 11.8004 \\
\hline & 2005 & 6609 & 11.3670 \\
\hline & 2004 & 6338 & 10.9009 \\
\hline & 2003 & 6192 & 10.6498 \\
\hline & 2007 & 5941 & 10.2181 \\
\hline & 2002 & 5736 & 9.8655 \\
\hline & 2010 & 5276 & 9.0743 \\
\hline & 2008 & 5207 & 8.9557 \\
\hline & 2009 & 5169 & 8.8903 \\
\hline & 2001 & 4813 & 8.2780 \\
\hline
\end{tabular}


"race" replacing "ethnic" includes 3 categorical data: "black", "white" and "other"; "Agegroup" replacing "age" has 4 data: "50-", “50-59", "60-69" and "70+". Among 58231 screens, 89 screens are with missing or mistaken information and removed for analysis. It makes a total of 58142 screens for the following statistical analysis. The data structure is present in Table 1.

2. Analysis methods

SAS (V9.2) and SAS enterprise were used to analysis the De-identified breast cancer screen data. At first the analysis based on screen number was done. The proportion of the screens based on 4 age groups, 3 races, 3 insurance systems, and 3 screen locations from 2001-2010 is shown. The thesis also presents the disparities of screen frequency for different combinations and the disparities of pathology code based on age group, race, insurance system, and screen locations. Chi-square test to check the association (H0: Independent). Secondly, the analysis based on participants was performed which includes odds ratio calculation, $\mathrm{CMH}$ tests to check the conditional independence, the follow-up study, etc. Pearson and Spearman correlation coefficients were calculated to check the association. 


\section{CHAPTER III}

\section{RESULTS}

Table 2 shows the general characteristics of the study population. The distribution and the percentage of demographic characteristics from the beginning (2001) to ending (2010) years are presented. Women aged less than 50 years old are more likely to take the screen $(39.68 \%)$. Aged group from $50-59$ is $2^{\text {nd }}(32.75 \%)$, followed by age group $60-69$ $(17.70 \%)$, women older than 70 years is the last $(9.86 \%)$; White women who go to screen are about twice more than black women (63.82\% for white vs. $27.95 \%$ for black), women with other race are the least (8.23\%). The screen percentage of $39.55 \%$ for uninsured women is little higher than the percentage of $36.23 \%$ for private insured women, the public insured women only have $24.22 \%$. For location, people are more likely going to partnership clinical (43.49\%), then corporate (33.23\%). The last one is partnership community (23.39\%). The year of 2006 has the highest percentage of $11.80 \%, 2001$ has the lowest one $8.28 \%$.

Figures 1-3 are the diagrams of screen frequency of age group from 2001 to 2010 for different race. The trend patterns for all races are the same: the older group, the less frequency. So the highest frequency is for age group less than 50 and lowest frequency is for age group older than 70 . For black, the highest frequency is 835 which happened in 2003 , the lowest is 78 in 2007 ; for white, the highest is 1633 in the year of 2004, the lowest is 248 in the year of 2009; For other, the highest number is 593 in 2007 , and the lowest number is 4 in 2001 . 
Table 2

Proportion of Participants in the breast cancer screens

\begin{tabular}{|c|c|c|c|c|c|c|c|c|c|c|c|}
\hline \multicolumn{12}{|c|}{ year } \\
\hline \multicolumn{12}{|c|}{ Age group (count/percent) } \\
\hline & 2001 & 2002 & 2003 & 2004 & 2005 & 2006 & 2007 & 2008 & 2009 & 2010 & Total \\
\hline 50- & $\begin{array}{r}1956 \\
3.36 \\
\end{array}$ & $\begin{array}{r}2350 \\
4.04\end{array}$ & $\begin{array}{r}2477 \\
4.26\end{array}$ & $\begin{array}{r}2550 \\
4.39 \\
\end{array}$ & $\begin{array}{r}2656 \\
4.57\end{array}$ & $\begin{array}{r}2652 \\
4.56\end{array}$ & $\begin{array}{r}2312 \\
3.98 \\
\end{array}$ & $\begin{array}{r}2037 \\
3.50 \\
\end{array}$ & $\begin{array}{r}2065 \\
3.55 \\
\end{array}$ & $\begin{array}{r}2018 \\
3.47 \\
\end{array}$ & $\begin{array}{r}23073 \\
39.68\end{array}$ \\
\hline $50-59$ & $\begin{array}{r}1483 \\
2.55\end{array}$ & $\begin{array}{r}1725 \\
2.97\end{array}$ & $\begin{array}{r}1920 \\
3.30\end{array}$ & $\begin{array}{r}1954 \\
3.36\end{array}$ & $\begin{array}{r}2056 \\
3.54\end{array}$ & $\begin{array}{r}2279 \\
3.92\end{array}$ & $\begin{array}{r}2063 \\
3.55\end{array}$ & \begin{tabular}{r|}
1799 \\
3.09
\end{tabular} & $\begin{array}{r}1836 \\
3.16\end{array}$ & $\begin{array}{r}1929 \\
3.32\end{array}$ & $\begin{array}{r}19044 \\
32.75\end{array}$ \\
\hline $60-69$ & $\begin{array}{r}903 \\
1.55\end{array}$ & $\begin{array}{r}1043 \\
1.79\end{array}$ & $\begin{array}{r}1114 \\
1.92\end{array}$ & $\begin{array}{r}1136 \\
1.95\end{array}$ & $\begin{array}{r}1123 \\
1.93\end{array}$ & $\begin{array}{l}1165 \\
2.00\end{array}$ & $\begin{array}{r}1031 \\
1.77\end{array}$ & $\begin{array}{r}935 \\
1.61\end{array}$ & $\begin{array}{r}901 \\
1.55\end{array}$ & $\begin{array}{r}940 \\
1.62\end{array}$ & $\begin{array}{r}10291 \\
17.70\end{array}$ \\
\hline $70+$ & $\begin{array}{r}471 \\
0.81\end{array}$ & $\begin{array}{r}618 \\
1.06\end{array}$ & $\begin{array}{l}681 \\
1.17\end{array}$ & $\begin{array}{r}698 \\
1.20\end{array}$ & $\begin{array}{r}774 \\
1.33\end{array}$ & $\begin{array}{r}765 \\
1.32\end{array}$ & $\begin{array}{r}535 \\
0.92\end{array}$ & $\begin{array}{l}436 \\
0.75\end{array}$ & $\begin{array}{l}367 \\
0.63\end{array}$ & $\begin{array}{r}389 \\
0.67\end{array}$ & $\begin{array}{r}5734 \\
9.86\end{array}$ \\
\hline \multicolumn{12}{|l|}{ Race } \\
\hline Black & $\begin{array}{r}1517 \\
2.61\end{array}$ & $\begin{array}{r}1762 \\
3.03\end{array}$ & $\begin{array}{r}2018 \\
3.47\end{array}$ & $\begin{array}{r}1919 \\
3.30\end{array}$ & $\begin{array}{r}2060 \\
3.54\end{array}$ & $\begin{array}{r}2070 \\
3.56\end{array}$ & $\begin{array}{r}995 \\
1.71\end{array}$ & $\begin{array}{r}1115 \\
1.92\end{array}$ & $\begin{array}{r}1373 \\
2.36\end{array}$ & $\begin{array}{r}1423 \\
2.45\end{array}$ & $\begin{array}{r}16252 \\
27.95\end{array}$ \\
\hline Other & $\begin{array}{r}148 \\
0.25\end{array}$ & $\begin{array}{r}157 \\
0.27\end{array}$ & $\begin{array}{r}189 \\
0.33\end{array}$ & $\begin{array}{l}263 \\
0.45\end{array}$ & $\begin{array}{r}485 \\
0.83\end{array}$ & $\begin{array}{r}493 \\
0.85\end{array}$ & $\begin{array}{r}1324 \\
2.28\end{array}$ & $\begin{array}{r}882 \\
1.52\end{array}$ & $\begin{array}{r}374 \\
0.64\end{array}$ & $\begin{array}{r}471 \\
0.81\end{array}$ & $\begin{array}{r}4786 \\
8.23\end{array}$ \\
\hline White & $\begin{array}{r}3148 \\
5.41 \\
\end{array}$ & $\begin{array}{r}3817 \\
6.56 \\
\end{array}$ & $\begin{array}{r}3985 \\
6.85\end{array}$ & $\begin{array}{r}4156 \\
7.15 \\
\end{array}$ & $\begin{array}{r}4064 \\
6.99\end{array}$ & $\begin{array}{r}4298 \\
7.39\end{array}$ & $\begin{array}{r}3622 \\
6.23 \\
\end{array}$ & $\begin{array}{r}3210 \\
5.52\end{array}$ & $\begin{array}{r}3422 \\
5.89\end{array}$ & $\begin{array}{r}3382 \\
5.82\end{array}$ & $\begin{array}{r}37104 \\
63.82\end{array}$ \\
\hline \multicolumn{12}{|l|}{ Insured } \\
\hline $\begin{array}{l}\text { Private } \\
\text { Insured }\end{array}$ & $\begin{array}{r}1839 \\
3.16 \\
\end{array}$ & $\begin{array}{r}1950 \\
3.35\end{array}$ & $\begin{array}{r}2023 \\
3.48 \\
\end{array}$ & $\begin{array}{r}2133 \\
3.67 \\
\end{array}$ & $\begin{array}{r}2401 \\
4.13\end{array}$ & $\begin{array}{r}2506 \\
4.31\end{array}$ & $\begin{array}{r}2159 \\
3.71 \\
\end{array}$ & $\begin{array}{r}1978 \\
3.40\end{array}$ & $\begin{array}{r}2101 \\
3.61 \\
\end{array}$ & $\begin{array}{r}1972 \\
3.39\end{array}$ & $\begin{array}{r}21062 \\
36.23\end{array}$ \\
\hline $\begin{array}{l}\text { Public } \\
\text { Insured }\end{array}$ & $\begin{array}{r}1150 \\
1.98 \\
\end{array}$ & $\begin{array}{r}1414 \\
2.43\end{array}$ & $\begin{array}{r}1667 \\
2.87\end{array}$ & $\begin{array}{r}1699 \\
2.92\end{array}$ & $\begin{array}{r}1846 \\
3.17\end{array}$ & $\begin{array}{r}1817 \\
3.13\end{array}$ & $\begin{array}{r}1430 \\
2.46\end{array}$ & $\begin{array}{r}1130 \\
1.94\end{array}$ & $\begin{array}{r}957 \\
1.65\end{array}$ & $\begin{array}{r}973 \\
1.67\end{array}$ & $\begin{array}{r}14083 \\
24.22\end{array}$ \\
\hline $\begin{array}{l}\text { Uninsur } \\
\text { ed }\end{array}$ & $\begin{array}{r}1824 \\
3.14 \\
\end{array}$ & $\begin{array}{r}2372 \\
4.08\end{array}$ & $\begin{array}{r}2502 \\
4.30\end{array}$ & $\begin{array}{r}2506 \\
4.31\end{array}$ & $\begin{array}{r}2362 \\
4.06\end{array}$ & $\begin{array}{r}2538 \\
4.37\end{array}$ & $\begin{array}{r}2352 \\
4.05\end{array}$ & $\begin{array}{r}2099 \\
3.61\end{array}$ & $\begin{array}{r}2111 \\
3.63\end{array}$ & $\begin{array}{r}2331 \\
4.01\end{array}$ & $\begin{array}{r}22997 \\
39.55\end{array}$ \\
\hline \multicolumn{12}{|l|}{ Location } \\
\hline Corporate & $\begin{array}{r}1883 \\
3.24\end{array}$ & $\begin{array}{r}2121 \\
3.65\end{array}$ & $\begin{array}{r}2147 \\
3.69\end{array}$ & $\begin{array}{r}2134 \\
3.67\end{array}$ & $\begin{array}{r}2200 \\
3.78\end{array}$ & $\begin{array}{r}2326 \\
4.00\end{array}$ & $\begin{array}{r}1785 \\
3.07\end{array}$ & $\begin{array}{r}1539 \\
2.65\end{array}$ & $\begin{array}{r}1661 \\
2.86\end{array}$ & $\begin{array}{r}1523 \\
2.62\end{array}$ & $\begin{array}{r}19319 \\
33.23\end{array}$ \\
\hline $\begin{array}{l}\text { Partnership } \\
\text { clinic }\end{array}$ & $\begin{array}{r}1976 \\
3.40\end{array}$ & $\begin{array}{r}2535 \\
4.36\end{array}$ & $\begin{array}{r}2757 \\
4.74\end{array}$ & $\begin{array}{r}2748 \\
4.73\end{array}$ & $\begin{array}{r}2882 \\
4.96\end{array}$ & $\begin{array}{r}3007 \\
5.17\end{array}$ & $\begin{array}{r}2723 \\
4.68\end{array}$ & $\begin{array}{r}2518 \\
4.33\end{array}$ & $\begin{array}{r}2122 \\
3.65\end{array}$ & $\begin{array}{r}2016 \\
3.47\end{array}$ & $\begin{array}{r}25284 \\
43.49\end{array}$ \\
\hline $\begin{array}{l}\text { Partnership } \\
\text { community }\end{array}$ & $\begin{array}{r}954 \\
1.64\end{array}$ & $\begin{array}{r}1080 \\
1.86\end{array}$ & $\begin{array}{r}1288 \\
2.22\end{array}$ & $\begin{array}{r}1456 \\
2.50\end{array}$ & $\begin{array}{r}1527 \\
2.63\end{array}$ & $\begin{array}{r}1528 \\
2.63\end{array}$ & $\begin{array}{r}1433 \\
2.46\end{array}$ & $\begin{array}{r}1150 \\
1.98\end{array}$ & $\begin{array}{r}1386 \\
2.38\end{array}$ & $\begin{array}{r}1737 \\
2.99\end{array}$ & $\begin{array}{r}13539 \\
23.29\end{array}$ \\
\hline Total & $\begin{array}{r}4813 \\
8.28\end{array}$ & $\begin{array}{r}5736 \\
9.87\end{array}$ & $\begin{array}{r}6192 \\
10.65\end{array}$ & $\begin{array}{r}6338 \\
10.90\end{array}$ & $\begin{array}{r}6609 \\
11.37\end{array}$ & $\begin{array}{r}6861 \\
11.80\end{array}$ & $\begin{array}{r}5941 \\
10.22\end{array}$ & $\begin{array}{r}5207 \\
8.96\end{array}$ & $\begin{array}{r}5169 \\
8.89\end{array}$ & $\begin{array}{r}5276 \\
9.07\end{array}$ & $\begin{array}{r}58142 \\
100.00\end{array}$ \\
\hline
\end{tabular}

Figures 4-6 are the diagrams of screen frequency from 2001-2010 for age group

with different insurance system. The patterns of "private insured" and 'uninsured' are the

same, but the pattern of "public insured" is reversed. It is understandable because "public 


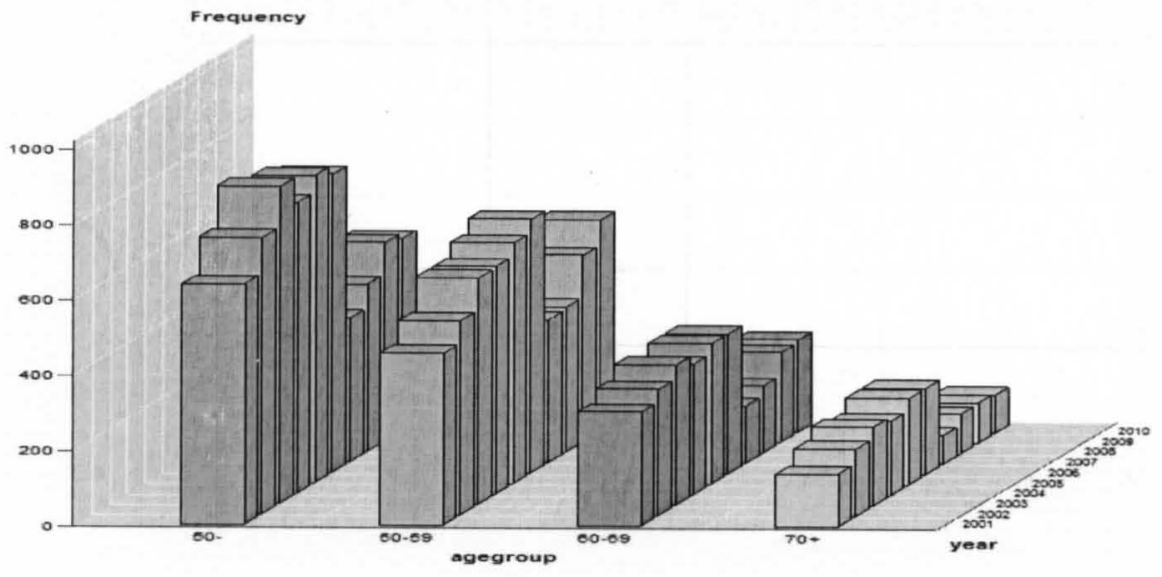

Figure 1. Screen frequency of agegroup over 10 years for race $=$ black

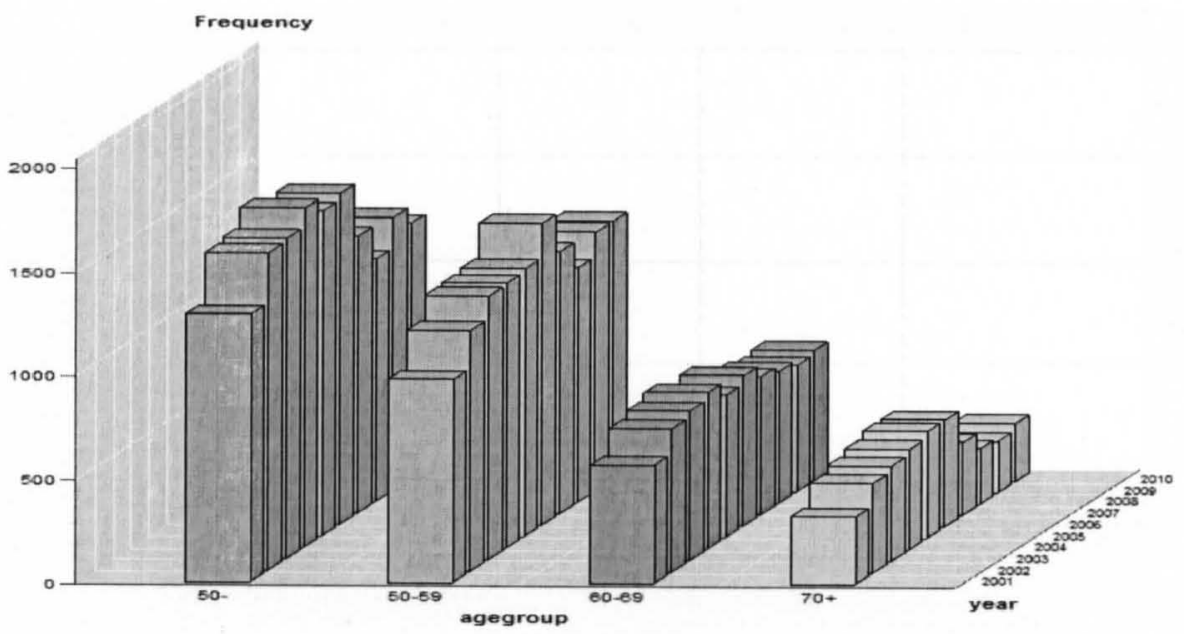

Figure 2. Screen frequency of agegroup over 10 years for race $=$ white

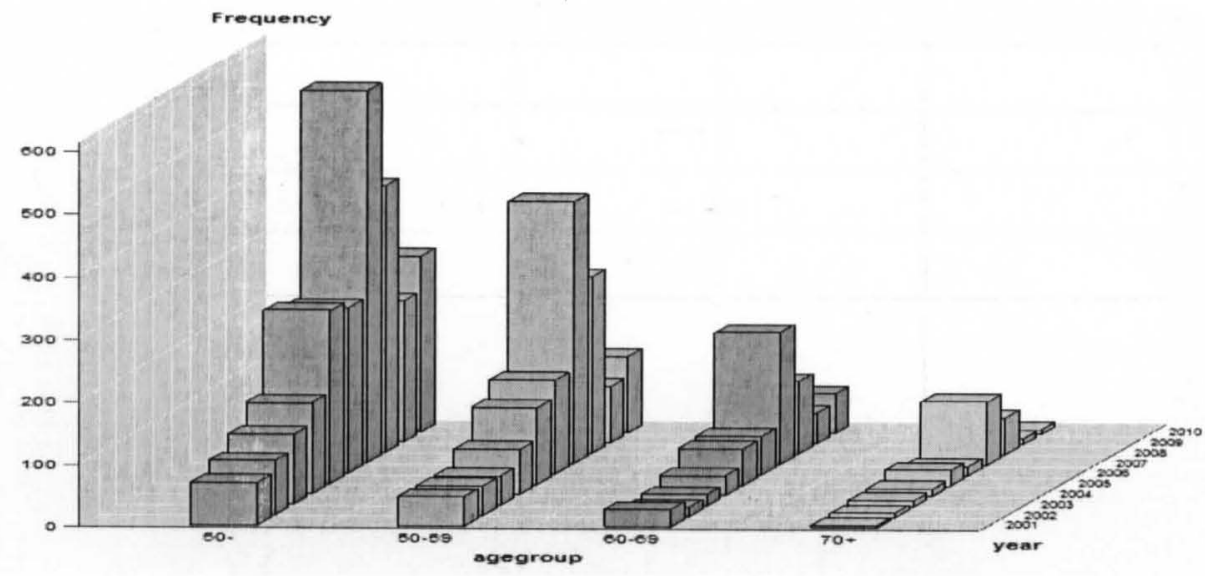

Figure 3. Screen frequency of agegroup over 10 years for race $=$ other 
insured" are Medicare and medicaid which are always issued to older women. For "private insured", the highest number is 1174 for women younger than 50 and in year 2005, the lowest is 34 for women older than 70 and in year 2004. For "public insured", the highest one is 709 for women older than 70 and in year 2005, the lowest one is 168 for women younger than 50 and in year 2001. For "uninsured", the highest is 1235 for people less than 50 and in the year of 2006, the lowest is 6 for people older than 70 and in year of 2010 .

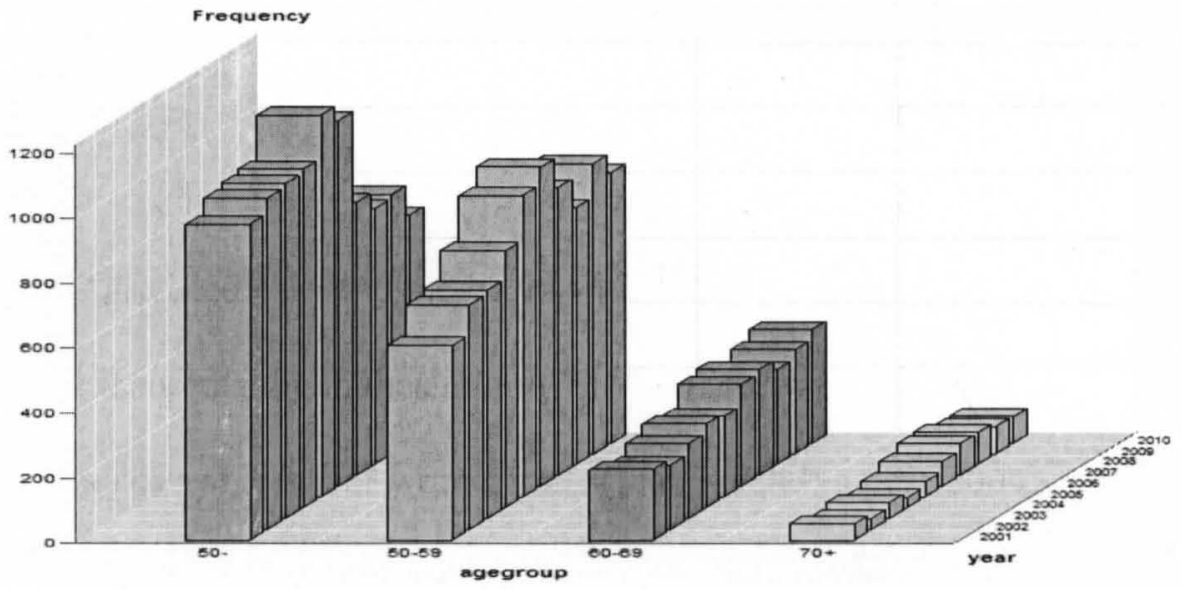

Figure 4. Screen frequency of agegroup over 10 years at insured $=$ private insured

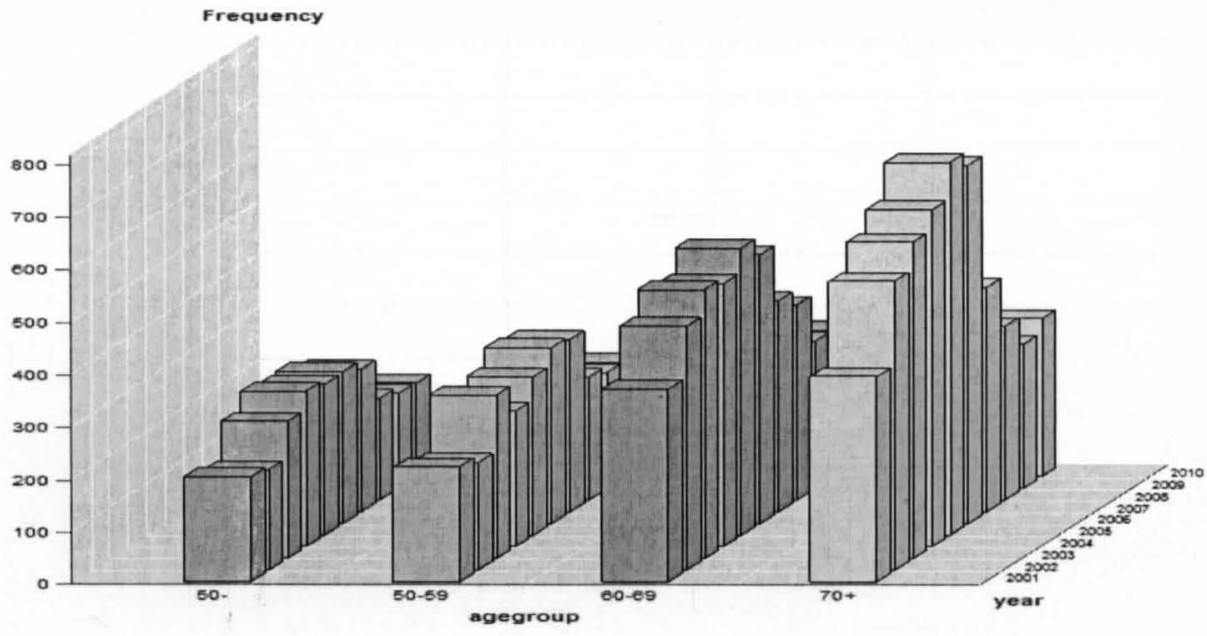

Figure 5. Screen frequency of agegroup over 10 years at insured $=$ public insured 


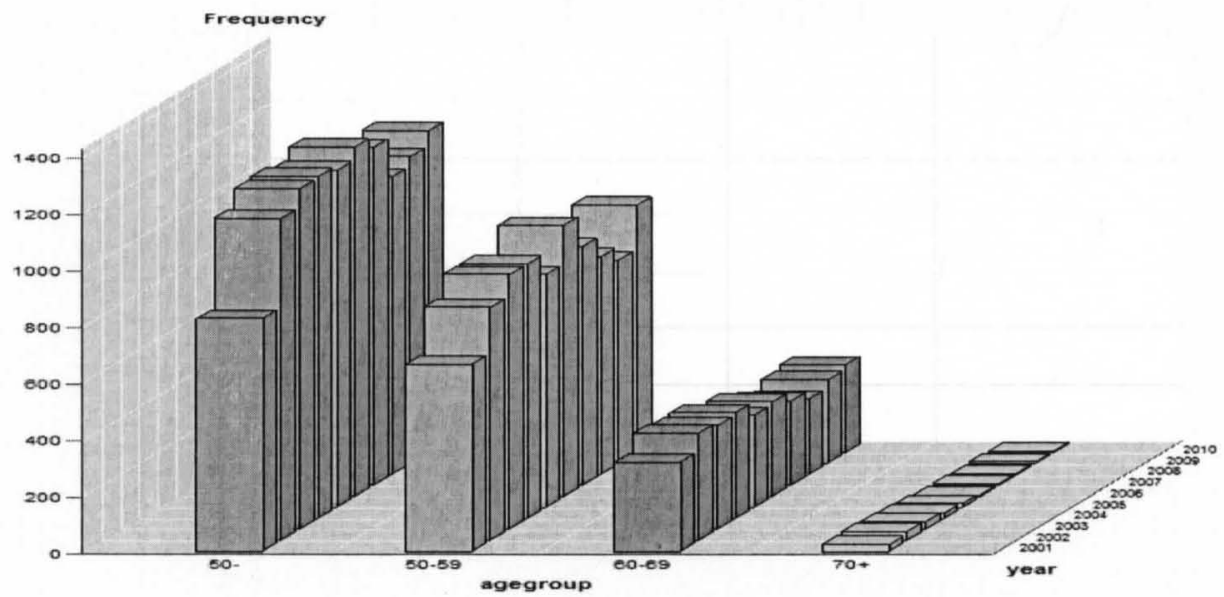

Figure 6. Screen frequency of agegroup over 10 years at insured $=$ uninsured

Figures 7-9 are the diagrams of screen frequency for different age group at different location. The patterns of "corporate" or "partnership clinic" or "partnership community" are similar. The highest frequency always happens for age group "50-" and the lowest frequency is for age group "70+". So at location = "corporate", the highest count is 965 in year 2002 and lowest count is 92 in year 2010; at location = "partnership clinic", the highest is 1196 in 2006 and the lowest is 108 in 2010; at location = "partnership community", the highest and lowest are 630 in 2010 and 145 in 2008, respectively.

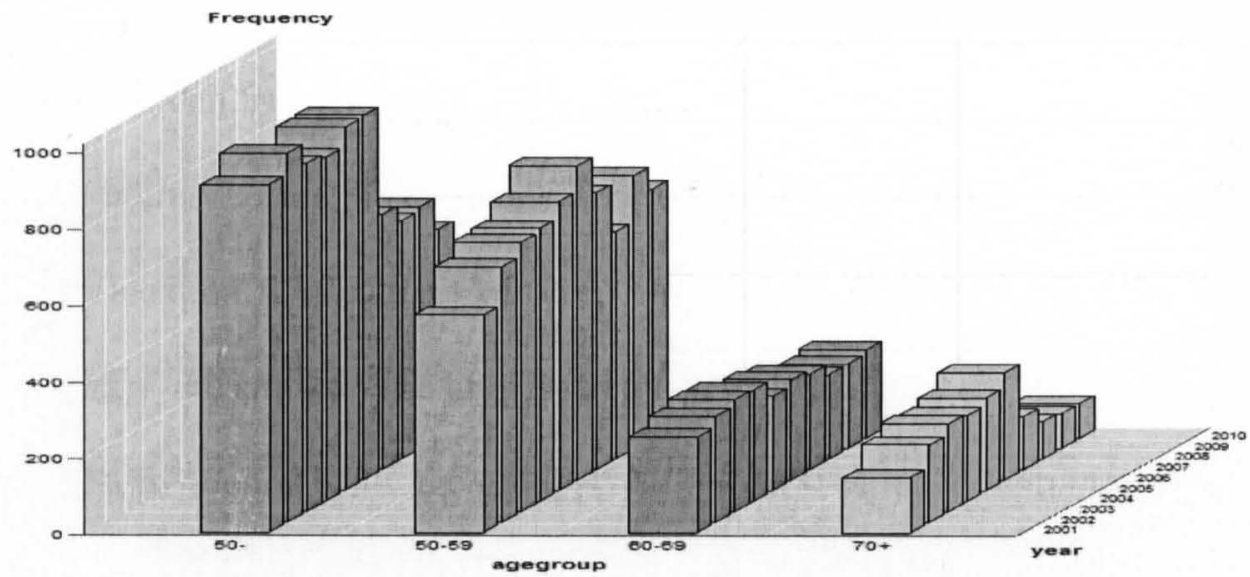

Figure 7. Screen frequency of agegroup over 10 years at location $=$ corporate 


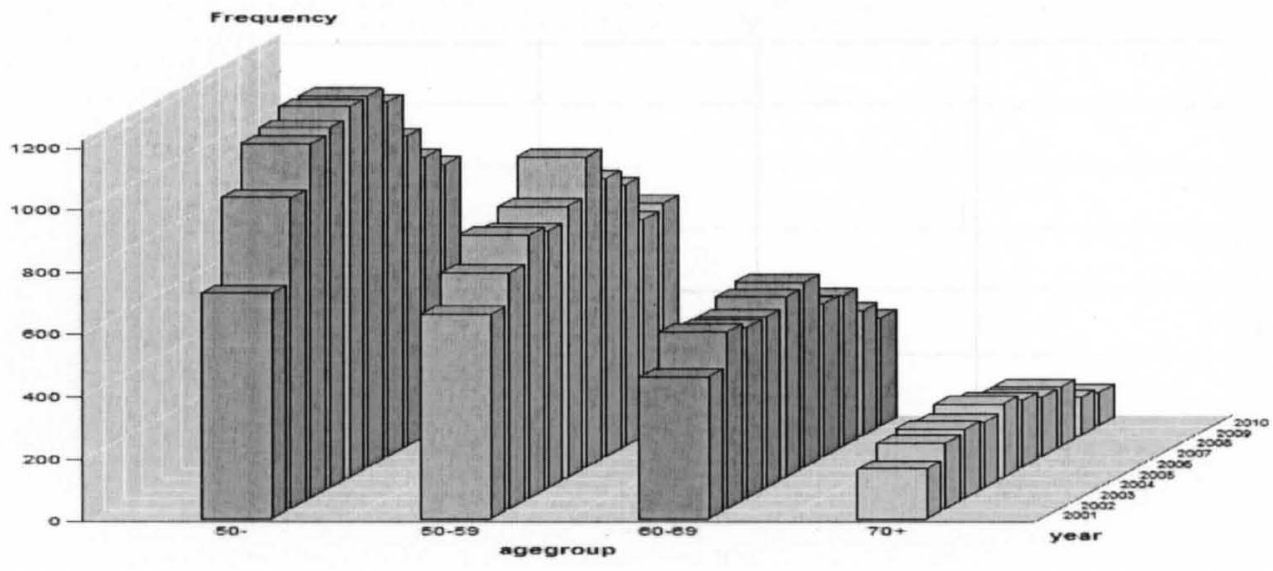

Figure 8. Screen frequency of agegroup over 10 years at location = partnership clinic

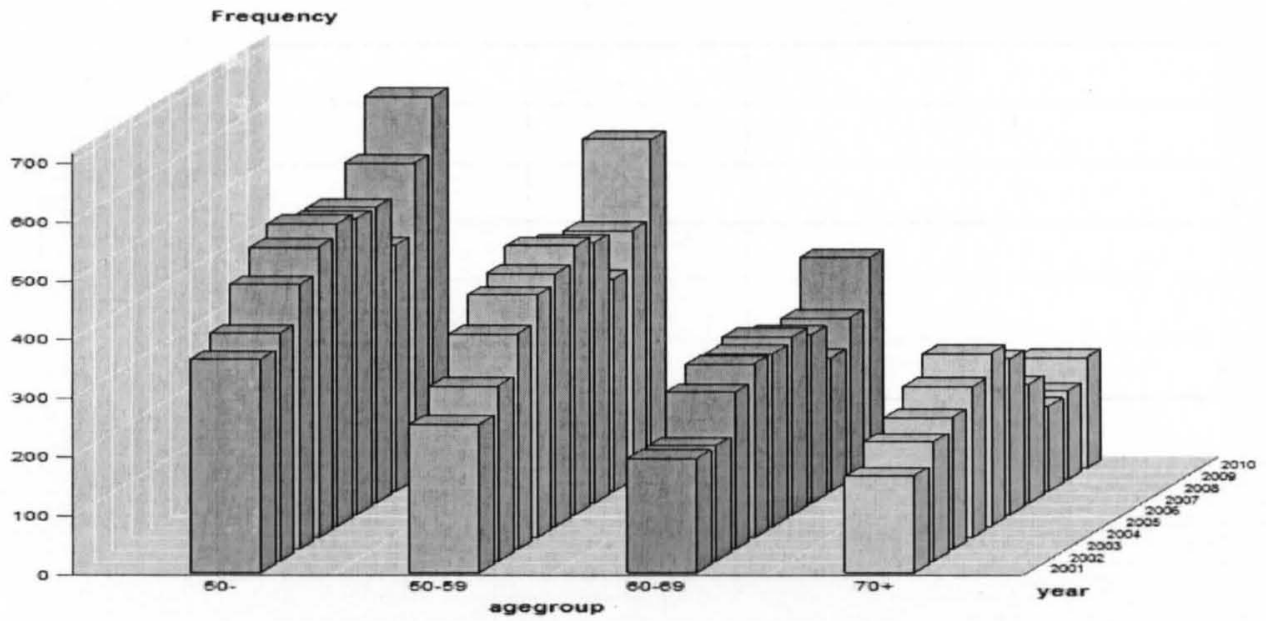

Figure 9. Screen frequency of agegroup over 10 years at location=partnership community

Another important concern is the disparities of pathology results of screens based on different insurance system, age groups, and races. As mentioned before, if any abnormal was found during the screen, a further exam was performed such as biopsy or ultrasound. The code (pathology code) represents seven different pathology results. $0=$ "No Biopsy", 1 = "Benign", 2 = "CYST ASPIRATION", 3 = "Negative", 4 = "High Risk", 5 ="INCONCLUSIVE", and 6 = "MALIGNANT". Table 3 shows the frequency and percentage under different pathology code for all age groups, races, and insurance 
Table 3

Pathology result based on age group/race/insured

\begin{tabular}{|c|r|r|r|r|r|r|r|r|}
\hline \multicolumn{7}{|c|}{ Pathology Code } \\
\hline \multicolumn{2}{|c|}{ Age group (count/percent of column) } \\
\hline & 0 & 1 & 2 & 3 & 4 & 5 & 6 & Total \\
\hline $50-$ & 22662 & 266 & 73 & 9 & 11 & 1 & 51 & 23073 \\
& 39.63 & 52.57 & 46.50 & 40.91 & 28.21 & 25.00 & 21.89 & \\
\hline $50-59$ & 18724 & 158 & 50 & 9 & 20 & 1 & 82 & 19044 \\
& 32.75 & 31.23 & 31.85 & 40.91 & 51.28 & 25.00 & 35.19 & \\
\hline $60-69$ & 10134 & 62 & 24 & 2 & 6 & 0 & 63 & 10291 \\
& 17.72 & 12.25 & 15.29 & 9.09 & 15.38 & 0.00 & 27.04 & \\
\hline $70+$ & 5661 & 20 & 10 & 2 & 2 & 2 & 37 & 5734 \\
& 9.90 & 3.95 & 6.37 & 9.09 & 5.13 & 50.00 & 15.88 & \\
\hline Race & & & & & & & & \\
\hline Black & 15953 & 141 & 52 & 9 & 15 & 2 & 80 & 16252 \\
& 27.90 & 27.87 & 33.12 & 40.91 & 38.46 & 50.00 & 34.33 & \\
\hline Other & 4677 & 78 & 14 & 1 & 2 & 0 & 14 & 4786 \\
& 8.18 & 15.42 & 8.92 & 4.55 & 5.13 & 0.00 & 6.01 & \\
\hline White & 36551 & 287 & 91 & 12 & 22 & 2 & 139 & 37104 \\
& 63.92 & 56.72 & 57.96 & 54.55 & 56.41 & 50.00 & 59.66 & \\
\hline Insured & & & & & & & & \\
\hline Private & 20838 & 126 & 32 & 2 & 10 & 0 & 54 & 21062 \\
Insured & 36.44 & 24.90 & 20.38 & 9.09 & 25.64 & 0.00 & 23.18 & \\
\hline Public & 13900 & 78 & 27 & 2 & 7 & 2 & 67 & 14083 \\
Insured & 24.31 & 15.42 & 17.20 & 9.09 & 17.95 & 50.00 & 28.76 & \\
\hline Uninsured & 22443 & 302 & 98 & 18 & 22 & 2 & 112 & 22997 \\
& 39.25 & 59.68 & 62.42 & 81.82 & 56.41 & 50.00 & 48.07 & \\
\hline Total & 57181 & 506 & 157 & 22 & 39 & 4 & 233 & 58142 \\
\hline
\end{tabular}

systems. For code = 0, age group "50-", race = "white", and Insured = "uninsured" have the highest percent number, $39.63 \%, 63.92 \%$ and $39.25 \%$, respectively; For code $=6$, age group "50-59", race = "white", and Insured = "uninsured" have the highest \% like, $35.19 \%, 59.66 \%$ and $48.07 \%$, respectively; It is partially due to the uneven percentage of people coming to screen (Table 2). Besides, Chi-square tests were performed to test the association. For all three categorical variables, $\mathrm{P}$ values are less than 0.001 , which 
provide strong evidence of an association between "code (pathology code)" and all other three categorical variables (agegroup/race/insured). Because majority of people do not need biopsy (code $=0$ ), only 961 women are diagnosed with the other codes. Chi-square tests also were performed and all P values are less than 0.05 ( $<0.001$ for "agegroup", 0.0174 for "race", $<0.001$ for "insured"), which conclude the same result.

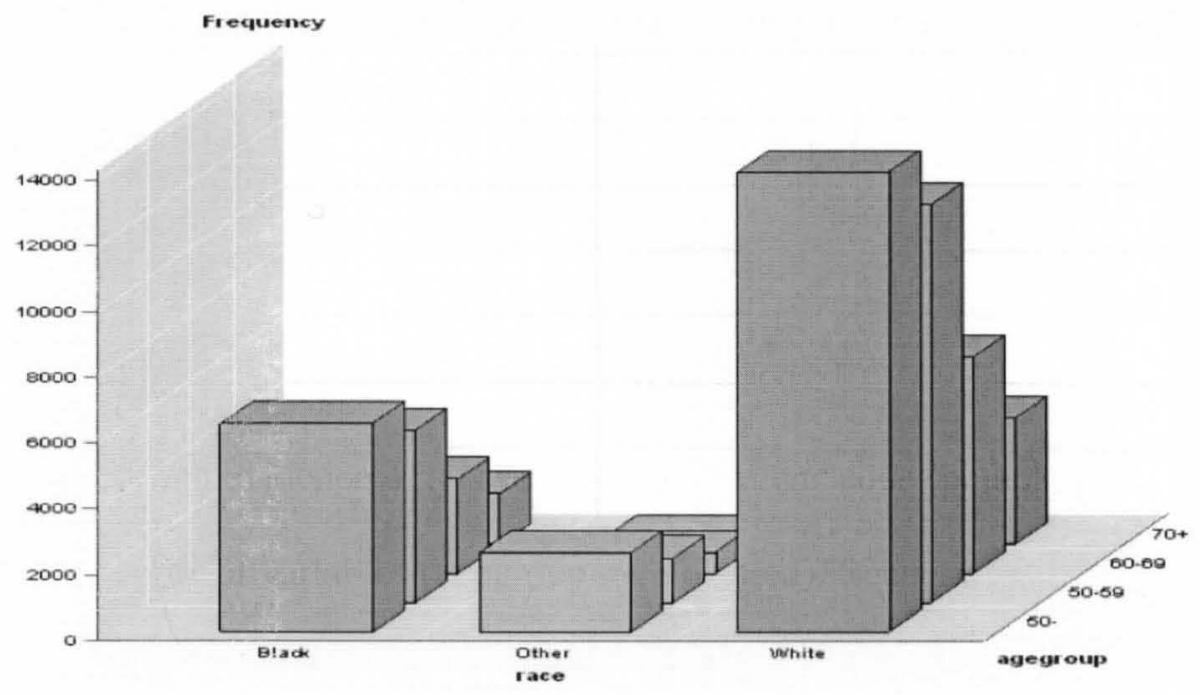

Figure 10. Trend of screen disparities on age group of each race at code $=0$

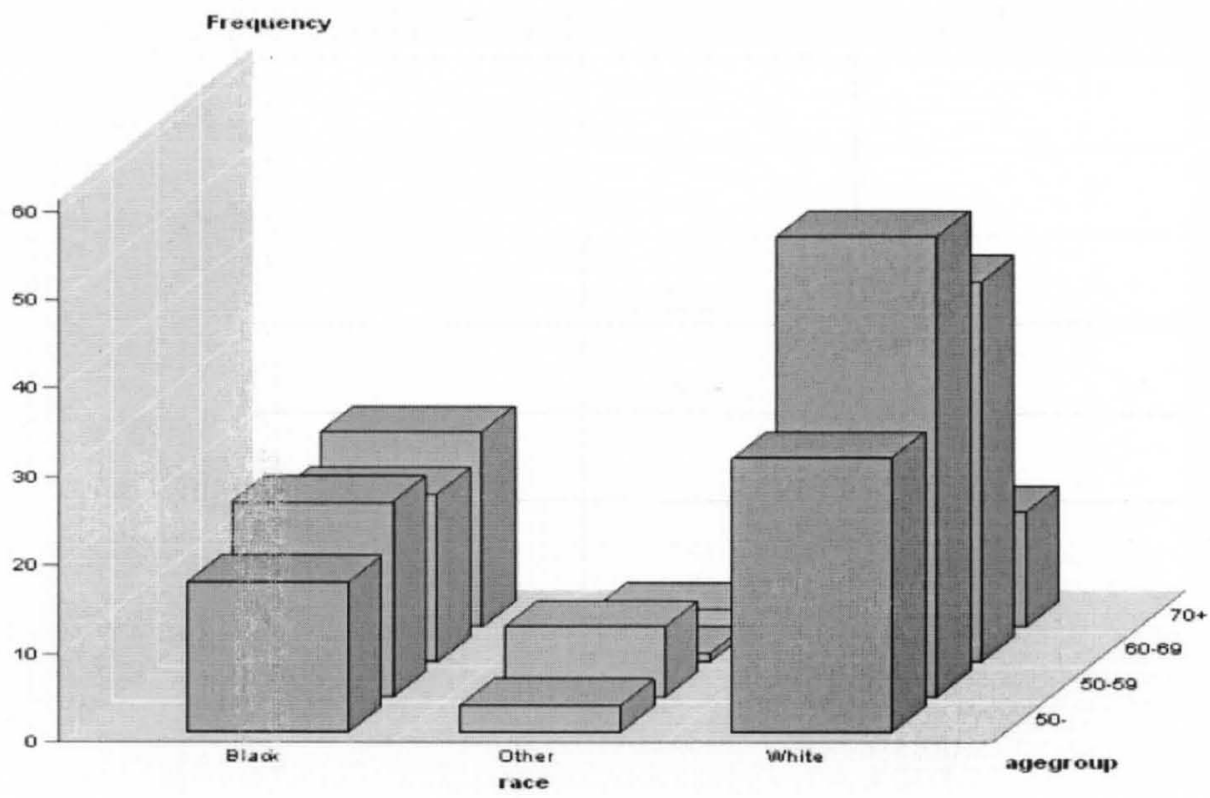

Figure 11. Trenc of screen disparities on age group of each race at code $=6$ 
Figure 10 and 11 show the trend of disparities of age group with different race at code $=0$ and 6 . The highest and lowest frequencies for code $=0$ are 13948 for "white" younger than 50, 243 for "other" older than 70; for code $=6$, they are 52 for "white" aged 50-59, 1 for "other" aged 60-69.

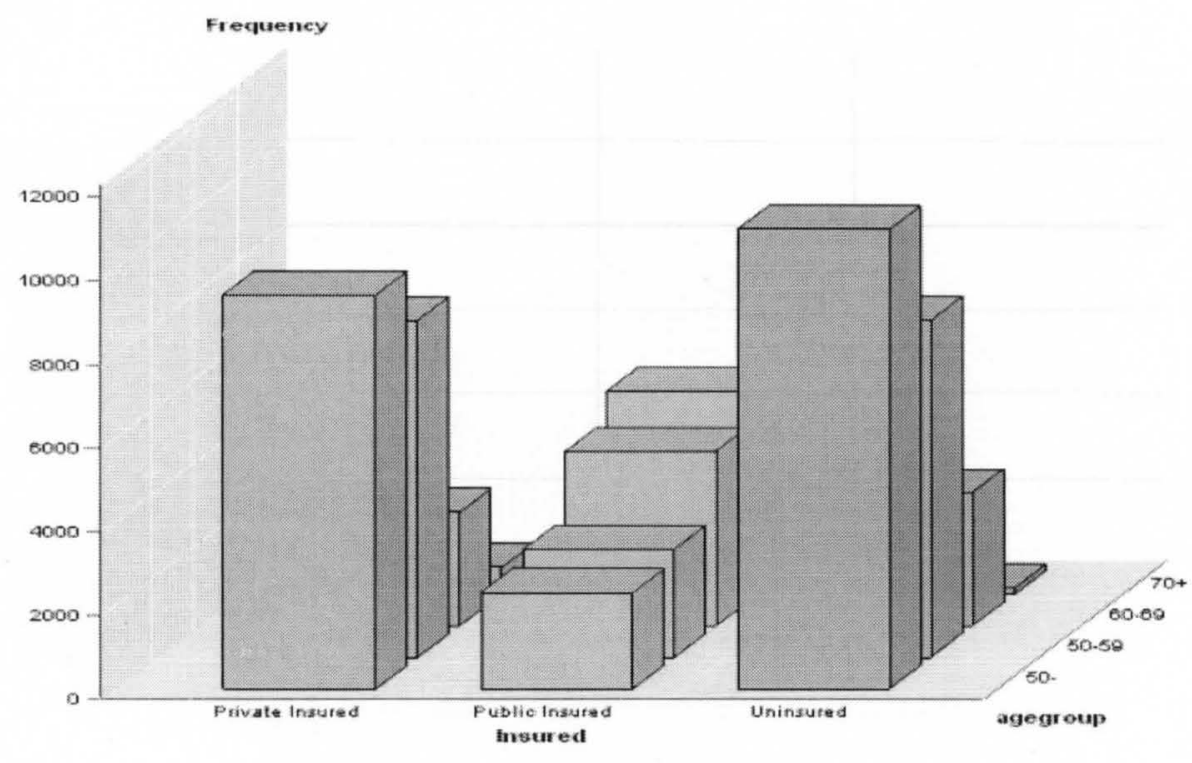

Figure 12. Trend of screen disparities on age group of each insurance at code $=0$

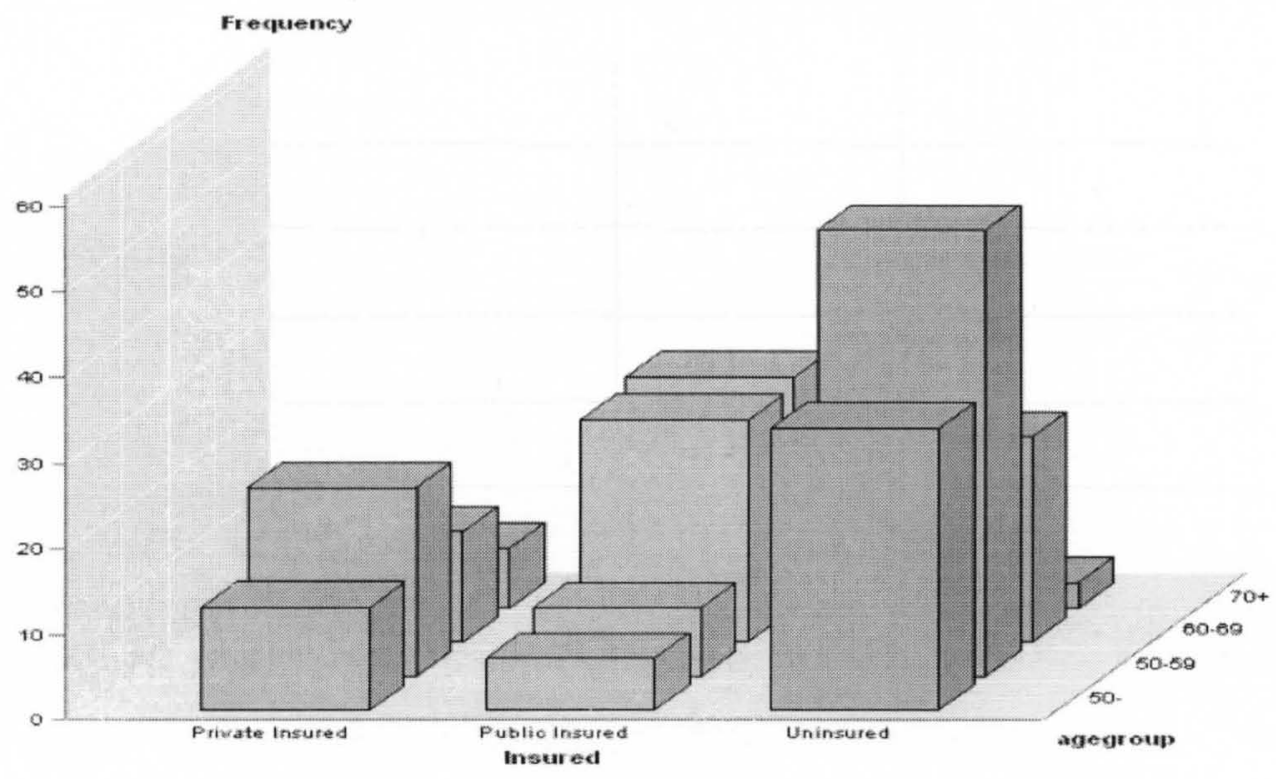

Figure 13. Trend of screen disparities on age group of each insurance at code $=6$ 
Table 4

Summary of patients for De-identified breast cancer screen data

\begin{tabular}{|c|c|c|c|}
\hline Variable & Value & $\begin{array}{r}\text { Frequency } \\
\text { Count }\end{array}$ & $\begin{array}{r}\text { Percent of Total } \\
\text { Frequency }\end{array}$ \\
\hline \multirow[t]{3}{*}{ Insured } & Uninsured & 9289 & 41.2844 \\
\hline & Private Insured & 8107 & 36.0311 \\
\hline & Public Insured & 5104 & 22.6844 \\
\hline \multirow[t]{3}{*}{ Location } & PARTNERSHIP CLINIC & 9319 & 41.4178 \\
\hline & CORPORATE & 7700 & 34.2222 \\
\hline & $\begin{array}{l}\text { PARTNERSHIP } \\
\text { COMMUNITY }\end{array}$ & 5481 & 24.3600 \\
\hline \multirow[t]{7}{*}{ Pcode } & 0 & 21713 & 96.5022 \\
\hline & 1 & 412 & 1.8311 \\
\hline & 6 & 199 & 0.8844 \\
\hline & 2 & 136 & 0.6044 \\
\hline & 4 & 31 & 0.1378 \\
\hline & 3 & 6 & 0.0267 \\
\hline & 5 & 3 & 0.0133 \\
\hline \multirow[t]{4}{*}{ agegroup } & $50-$ & 9888 & 43.9467 \\
\hline & $50-59$ & 6990 & 31.0667 \\
\hline & $60-69$ & 3476 & 15.4489 \\
\hline & $70+$ & 2146 & 9.5378 \\
\hline \multirow[t]{3}{*}{ race } & White & 14339 & 63.7289 \\
\hline & Black & 6003 & 26.6800 \\
\hline & Other & 2158 & 9.5911 \\
\hline \multirow[t]{10}{*}{ year } & 2006 & 2579 & 11.4622 \\
\hline & 2002 & 2423 & 10.7689 \\
\hline & 2005 & 2415 & 10.7333 \\
\hline & 2001 & 2358 & 10.4800 \\
\hline & 2004 & 2335 & 10.3778 \\
\hline & 2003 & 2316 & 10.2933 \\
\hline & 2010 & 2275 & 10.1111 \\
\hline & 2007 & 2208 & 9.8133 \\
\hline & 2009 & 1881 & 8.3600 \\
\hline & 2008 & 1710 & 7.6000 \\
\hline
\end{tabular}


Figure 12-13 are the diagrams of trend of disparities of age group with different insurance at code $=0$ and 6 respectively. For both codes, all the highest and lowest screen frequencies happened in categorical variable "Insured "= Uninsured. They are 10994 for women younger than 50 and 152 for women older than 70 at code $=0 ; 52$ for women aged 50-59 and 3 for women older than 70 at code $=6$.

Although a total number of screen is 58142 , actually only 22500 individuals participant the program. Because some women have multiple screens where different result might exist for each one, for each woman, only the case with maximum pathology code was chosen for analysis. The summary of patients is present as Table 4.

Table 5

Odds ratio of Race/Insurance for different age group

\begin{tabular}{|c|c|c|c|c|c|}
\hline & & \multicolumn{3}{|c|}{ Insurance } & \multirow{2}{*}{$\begin{array}{l}\text { odds ratio } \\
95 \% \text { C. I. }\end{array}$} \\
\hline Age group & Race & Yes & No & Total & \\
\hline \multirow[t]{3}{*}{$50-$} & White & 3410 & 2584 & 5994 & \multirow{3}{*}{$\begin{array}{c}1.6686 \\
(1.5228,1.8282) \\
P<0.0001\end{array}$} \\
\hline & Black & 1199 & 1516 & 2715 & \\
\hline & Total & 4609 & 4100 & 8709 & \\
\hline \multirow[t]{3}{*}{$50-59$} & White & 2711 & 1833 & 4544 & \multirow{3}{*}{$\begin{array}{c}1.8572 \\
(1.666,2.0703) \\
P<0.0001\end{array}$} \\
\hline & Black & 833 & 1046 & 1879 & \\
\hline & Total & 3544 & 2879 & 6423 & \\
\hline \multirow[t]{3}{*}{$60-69$} & White & 1582 & 713 & 2295 & \multirow{3}{*}{$\begin{array}{c}0.9893 \\
(0.8377,1.1682) \\
\mathrm{P}=0.8988\end{array}$} \\
\hline & Black & 628 & 280 & 908 & \\
\hline & Total & 2210 & 993 & 3203 & \\
\hline \multirow[t]{3}{*}{$70+$} & White & 1488 & 47 & 1535 & \multirow{3}{*}{$\begin{array}{c}0.3776 \\
(0.1605,0.8886) \\
P=0.0205\end{array}$} \\
\hline & Black & 503 & 6 & 509 & \\
\hline & Total & 1991 & 53 & 2044 & \\
\hline
\end{tabular}

Table 4 shows white and black women are the majority ( $\sim 90 \%$ of population), so next we focus our analysis on this part of population. We replace variable "Insured" with "Insurance", combine "Private insured" and "Public insured" into Insurance = "yes", and 
define "Uninsured" as Insurance = "No". We also change "Pathology_code" into

"Pathology_result", and combine 0-3 into Pathology_result = "Negative" and 4-6 into

Pathology_result $=$ "Positive". There are 20342 women left for analysis.

Table 6

Odds ratio of Race/Pathology result for different age group

\begin{tabular}{|c|c|c|c|c|c|}
\hline & & \multicolumn{3}{|c|}{ Pathology_Result } & \multirow{2}{*}{$\begin{array}{l}\text { odds ratio } \\
95 \% \text { C. I. }\end{array}$} \\
\hline Age group & Race & Negative & Positive & Total & \\
\hline \multirow[t]{3}{*}{$50-$} & White & 5954 & 40 & 5994 & \multirow{3}{*}{$\begin{array}{c}0.9379 \\
(0.5308,1.6573) \\
P=0.8253\end{array}$} \\
\hline & Black & 2698 & 17 & 2715 & \\
\hline & Total & 8652 & 57 & 8709 & \\
\hline \multirow[t]{3}{*}{$50-59$} & White & 4465 & 50 & 4515 & \multirow{3}{*}{$\begin{array}{c}1.2584 \\
(0.7810,2.0276) \\
P=0.3439\end{array}$} \\
\hline & Black & 1845 & 26 & 1871 & \\
\hline & Total & 6310 & 76 & 6386 & \\
\hline \multirow[t]{3}{*}{$60-69$} & White & 2262 & 33 & 2295 & \multirow{3}{*}{$\begin{array}{c}1.3078 \\
(0.7248,2.3599) \\
P=0.3715\end{array}$} \\
\hline & Black & 891 & 17 & 908 & \\
\hline & Total & 3153 & 50 & 3203 & \\
\hline \multirow[t]{3}{*}{$70+$} & White & 1521 & 14 & 1535 & \multirow{3}{*}{$\begin{array}{c}4.4435 \\
(2.2275,8.8638) \\
P<0.0001\end{array}$} \\
\hline & Black & 489 & 20 & 509 & \\
\hline & Total & 2010 & 34 & 2044 & \\
\hline
\end{tabular}

Tables 5-7 present the calculated odds ratios and their $95 \%$ confidence intervals.

Table 5 shows age groups " 50 -" and "50-59" have odds ratio of 1.6686 and 1.8572 which means the odds of white people with insurance is $<2$ times of black people with insurance for those two age groups. Age group " $70+$ " is opposite, the odds of white women with insurance is only 0.4 time of black women with insurance. No much difference was found in odds between black and white for age group "60-69". From table 6, the significant result is only for age group " $70+$ ", the odds ratio is 4.4 , so the odds of white women with "Negative" pathology result is 4.4 times of black women. There is not much difference for other age groups. Table 7 is the odds ratio of Insurance/Pathology_result. The two 
non-significant age groups are "60-69" and "70+", for other age groups, the odds ratios are 2.26 for " $50-$ ", and 2.08 for " $50-59$ ". The odds of women with insurance "Yes" having "Negative" pathology result is $2.26 / 2.08$ times of the women with insurance "No" for age group "50-", "50-59" respectively.

Table 7

Odds ratio of Insurance/Pathology result for different age group

\begin{tabular}{|c|c|c|c|c|c|}
\hline & & \multicolumn{3}{|c|}{ Pathology_Result } & \multirow{2}{*}{$\begin{array}{l}\text { odds ratio } \\
95 \% \text { C. I. }\end{array}$} \\
\hline Ae group & Insurance & Negative & Positive & Total & \\
\hline \multirow[t]{3}{*}{$50-$} & Yes & 4590 & 19 & 4609 & \multirow{3}{*}{$\begin{array}{c}2.26 \\
(1.3009,3.9262) \\
P=0.003\end{array}$} \\
\hline & No & 4062 & 38 & 4100 & \\
\hline & 'Total & 8652 & 57 & 8709 & \\
\hline \multirow[t]{3}{*}{$50-59$} & Yes & 3632 & 30 & 3662 & \multirow{3}{*}{$\begin{array}{c}2.0796 \\
(1.3093,3.3029) \\
P=0.0015\end{array}$} \\
\hline & No & 2678 & 46 & 2724 & \\
\hline & Total & 6310 & 76 & 6386 & \\
\hline \multirow[t]{3}{*}{$60-69$} & Yes & 2179 & 31 & 2210 & \multirow{3}{*}{$\begin{array}{c}1.3712 \\
(0.7708,2.4392) \\
P=0.2809\end{array}$} \\
\hline & No & 974 & 19 & 993 & \\
\hline & Total & 3153 & 50 & 3203 & \\
\hline \multirow[t]{3}{*}{$70+$} & Yes & 1959 & 32 & 1991 & \multirow{3}{*}{$\begin{array}{c}2.4007 \\
(0.5601,10.2896) \\
P=0.2236\end{array}$} \\
\hline & No & 51 & 2 & 53 & \\
\hline & Total & 2010 & 34 & 2044 & \\
\hline
\end{tabular}

Tables 8 and 9 are the follow- up study. $\mathrm{N}$ is the number of screens for an individual. The maximum number that each person can take the screen from this data set is $\mathrm{N}=17$. The majority ( $45 \%$ ) only take screen once. About $19 \%$ of women take twice, $12 \%$ take triple. Only one person took 17 times. Pearson and Spearman correlation coefficients were calculated to check the association. For agegroup by N, Person coefficient is 0.0605 with $95 \%$ C.I. $(0.0477,0.0733)$ and Spearman coefficient is 0.0714 with $95 \%$ C. I. $(0.0584,0.0844)$, which show a weakly positive association between 
agegroup and $\mathrm{N}$; Pearson and Spearman correlation coefficients for race by $\mathrm{N}$ are -0.0152 with $95 \%$ C.I $(-0.0284,-0.002)$ and -0.0146 with $95 \%$ C.I. $(-0.0277,-0.0014)$ respectively, which means a weakly negative association. Pearson and Spearman correlation coefficients for Insured by N are -0.0288 with $95 \%$ C.I $(-0.0419,-0.0156)$ and -0.0019 with $95 \%$ C.I $(-0.0149,0.0112)$ respectively, there is no association between them. For pathology code by N,Pearson and Spearman correlation coefficients are 0.1701 with $95 \%$ C.I $(0.1539,0.1863)$ and 0.2154 with $95 \%$ C. I $(0.2051,0.2257)$ respectively, which show evidence of a positive association. 
Table 8

Summary of screen numbers for each agegroup/race/insured

\begin{tabular}{|c|c|c|c|c|c|c|c|c|c|c|c|c|c|c|c|c|c|c|}
\hline Age group & \multicolumn{18}{|c|}{ N (SCREEN NUMBER) } \\
\hline & 1 & 2 & 3 & 4 & 5 & 6 & 7 & 8 & 9 & 10 & 11 & 12 & 13 & 14 & 15 & 16 & 17 & Total \\
\hline 50 & $\begin{array}{r}4771 \\
21.20\end{array}$ & $\begin{array}{r}1951 \\
8.67\end{array}$ & $\begin{array}{r}1244 \\
5.53\end{array}$ & $\begin{array}{r}659 \\
2.93\end{array}$ & $\begin{array}{r}439 \\
1.95\end{array}$ & $\begin{array}{r}290 \\
1.29\end{array}$ & $\begin{array}{r}202 \\
0.90\end{array}$ & $\begin{array}{r}123 \\
0.55\end{array}$ & $\begin{array}{r}85 \\
0.38\end{array}$ & $\begin{array}{r}59 \\
0.26\end{array}$ & $\begin{array}{r}29 \\
0.13\end{array}$ & $\begin{array}{r}17 \\
0.08\end{array}$ & $\begin{array}{r}8 \\
0.04\end{array}$ & $\begin{array}{r}5 \\
0.02\end{array}$ & $\begin{array}{r}3 \\
0.01\end{array}$ & $\begin{array}{r}2 \\
0.01\end{array}$ & $\begin{array}{r}1 \\
0.00\end{array}$ & $\begin{array}{r}9888 \\
43.95\end{array}$ \\
\hline $50-59$ & $\begin{array}{r}2948 \\
13.10\end{array}$ & $\begin{array}{r}1276 \\
5.67\end{array}$ & $\begin{array}{r}916 \\
4.07\end{array}$ & $\begin{array}{r}614 \\
2.73\end{array}$ & $\begin{array}{r}382 \\
1.70\end{array}$ & $\begin{array}{r}290 \\
1.29\end{array}$ & $\begin{array}{r}199 \\
0.88\end{array}$ & $\begin{array}{r}128 \\
0.57\end{array}$ & $\begin{array}{r}93 \\
0.41\end{array}$ & $\begin{array}{r}88 \\
0.39\end{array}$ & $\begin{array}{r}29 \\
0.13\end{array}$ & $\begin{array}{r}11 \\
0.05\end{array}$ & $\begin{array}{r}7 \\
0.03\end{array}$ & $\begin{array}{r}4 \\
0.02\end{array}$ & $\begin{array}{r}3 \\
0.01\end{array}$ & $\begin{array}{r}2 \\
0.01\end{array}$ & $\begin{array}{r}0 \\
0.00\end{array}$ & $\begin{array}{r}6990 \\
31.07\end{array}$ \\
\hline $60-69$ & $\begin{array}{r}1402 \\
6.23\end{array}$ & $\begin{array}{r}639 \\
2.84\end{array}$ & $\begin{array}{r}400 \\
1.78\end{array}$ & $\begin{array}{l}317 \\
1.41\end{array}$ & $\begin{array}{r}226 \\
1.00\end{array}$ & $\begin{array}{r}187 \\
0.83\end{array}$ & $\begin{array}{r}110 \\
0.49\end{array}$ & $\begin{array}{r}80 \\
0.36\end{array}$ & $\begin{array}{r}40 \\
0.18\end{array}$ & $\begin{array}{r}44 \\
0.20\end{array}$ & $\begin{array}{r}19 \\
0.08\end{array}$ & $\begin{array}{r}3 \\
0.01\end{array}$ & $\begin{array}{r}6 \\
0.03\end{array}$ & $\begin{array}{r}2 \\
0.01\end{array}$ & $\begin{array}{r}1 \\
0.00\end{array}$ & $\begin{array}{r}0 \\
0.00\end{array}$ & $\begin{array}{r}0 \\
0.00\end{array}$ & $\begin{array}{r}3476 \\
15.45\end{array}$ \\
\hline $70+$ & $\begin{array}{r}978 \\
4.35\end{array}$ & $\begin{array}{l}407 \\
1.81\end{array}$ & $\begin{array}{r}256 \\
1.14\end{array}$ & $\begin{array}{r}159 \\
0.71\end{array}$ & $\begin{array}{r}121 \\
0.54\end{array}$ & $\begin{array}{r}75 \\
0.33\end{array}$ & $\begin{array}{r}59 \\
0.26\end{array}$ & $\begin{array}{r}43 \\
0.19\end{array}$ & $\begin{array}{r}23 \\
0.10\end{array}$ & $\begin{array}{r}13 \\
0.06\end{array}$ & $\begin{array}{r}7 \\
0.03\end{array}$ & $\begin{array}{r}4 \\
0.02\end{array}$ & $\begin{array}{r}1 \\
0.00\end{array}$ & $\begin{array}{r}0 \\
0.00\end{array}$ & $\begin{array}{r}0 \\
0.00\end{array}$ & $\begin{array}{r}0 \\
0.00\end{array}$ & $\begin{array}{r}0 \\
0.00\end{array}$ & $\begin{array}{r}2146 \\
9.54\end{array}$ \\
\hline \multicolumn{19}{|l|}{ Race } \\
\hline Black & $\begin{array}{r}2521 \\
11.20\end{array}$ & $\begin{array}{r}1147 \\
5.10\end{array}$ & $\begin{array}{r}772 \\
3.43\end{array}$ & $\begin{array}{r}514 \\
2.28\end{array}$ & $\begin{array}{r}330 \\
1.47\end{array}$ & $\begin{array}{r}275 \\
1.22\end{array}$ & $\begin{array}{r}175 \\
0.78\end{array}$ & $\begin{array}{r}113 \\
0.50\end{array}$ & $\begin{array}{r}70 \\
0.31\end{array}$ & $\begin{array}{r}40 \\
0.18\end{array}$ & $\begin{array}{r}22 \\
0.10\end{array}$ & $\begin{array}{r}14 \\
0.06\end{array}$ & $\begin{array}{r}3 \\
0.01\end{array}$ & $\begin{array}{r}4 \\
0.02\end{array}$ & $\begin{array}{r}1 \\
0.00\end{array}$ & $\begin{array}{r}2 \\
0.01\end{array}$ & $\begin{array}{r}0 \\
0.00\end{array}$ & $\begin{array}{r}6003 \\
26.68\end{array}$ \\
\hline Other & $\begin{array}{r}1138 \\
5.06\end{array}$ & $\begin{array}{l}379 \\
1.68\end{array}$ & $\begin{array}{r}256 \\
1.14\end{array}$ & $\begin{array}{r}132 \\
0.59\end{array}$ & $\begin{array}{r}93 \\
0.41\end{array}$ & $\begin{array}{r}61 \\
0.27\end{array}$ & $\begin{array}{r}38 \\
0.17\end{array}$ & $\begin{array}{r}32 \\
0.14\end{array}$ & $\begin{array}{r}10 \\
0.04\end{array}$ & $\begin{array}{r}7 \\
0.03\end{array}$ & $\begin{array}{r}5 \\
0.02\end{array}$ & $\begin{array}{r}1 \\
0.00\end{array}$ & $\begin{array}{r}3 \\
0.01\end{array}$ & $\begin{array}{r}1 \\
0.00\end{array}$ & $\begin{array}{r}2 \\
0.01\end{array}$ & $\begin{array}{r}0 \\
0.00\end{array}$ & $\begin{array}{r}0 \\
0.00\end{array}$ & $\begin{array}{r}2158 \\
9.59\end{array}$ \\
\hline White & $\begin{array}{r}6440 \\
28.62\end{array}$ & $\begin{array}{r}2747 \\
12.21\end{array}$ & $\begin{array}{r}1788 \\
7.95\end{array}$ & $\begin{array}{r}1103 \\
4.90\end{array}$ & $\begin{array}{r}745 \\
3.31\end{array}$ & $\begin{array}{r}506 \\
2.25\end{array}$ & $\begin{array}{r}357 \\
1.59\end{array}$ & $\begin{array}{r}229 \\
1.02\end{array}$ & $\begin{array}{r}161 \\
0.72\end{array}$ & $\begin{array}{r}157 \\
0.70\end{array}$ & $\begin{array}{r}57 \\
0.25\end{array}$ & $\begin{array}{r}20 \\
0.09\end{array}$ & $\begin{array}{r}16 \\
0.07\end{array}$ & $\begin{array}{r}6 \\
0.03\end{array}$ & $\begin{array}{r}4 \\
0.02\end{array}$ & $\begin{array}{r}2 \\
0.01\end{array}$ & $\begin{array}{r}1 \\
0.00\end{array}$ & $\begin{array}{r}14339 \\
63.73\end{array}$ \\
\hline \multicolumn{19}{|l|}{ Insured } \\
\hline $\begin{array}{l}\text { Private } \\
\text { Insured }\end{array}$ & $\begin{array}{r}3815 \\
16.96\end{array}$ & $\begin{array}{r}1473 \\
6.55\end{array}$ & $\begin{array}{r}940 \\
4.18\end{array}$ & $\begin{array}{r}536 \\
2.38\end{array}$ & $\begin{array}{l}375 \\
1.67\end{array}$ & $\begin{array}{r}299 \\
1.33\end{array}$ & $\begin{array}{r}216 \\
0.96\end{array}$ & $\begin{array}{r}141 \\
0.63\end{array}$ & $\begin{array}{r}110 \\
0.49\end{array}$ & $\begin{array}{r}118 \\
0.52\end{array}$ & $\begin{array}{r}41 \\
0.18\end{array}$ & $\begin{array}{r}24 \\
0.11\end{array}$ & $\begin{array}{r}6 \\
0.03\end{array}$ & $\begin{array}{r}8 \\
0.04\end{array}$ & $\begin{array}{r}3 \\
0.01\end{array}$ & $\begin{array}{r}2 \\
0.01\end{array}$ & $\begin{array}{r}0 \\
0.00\end{array}$ & $\begin{array}{r}8107 \\
36.03\end{array}$ \\
\hline $\begin{array}{l}\text { Public } \\
\text { Insured }\end{array}$ & $\begin{array}{r}2099 \\
9.33\end{array}$ & $\begin{array}{r}932 \\
4.14\end{array}$ & $\begin{array}{r}662 \\
2.94\end{array}$ & $\begin{array}{r}496 \\
2.20\end{array}$ & $\begin{array}{l}335 \\
1.49\end{array}$ & $\begin{array}{r}220 \\
0.98\end{array}$ & $\begin{array}{r}139 \\
0.62\end{array}$ & $\begin{array}{c}102 \\
0.45\end{array}$ & $\begin{array}{r}52 \\
0.23\end{array}$ & $\begin{array}{r}39 \\
0.17\end{array}$ & $\begin{array}{r}19 \\
0.08\end{array}$ & $\begin{array}{r}3 \\
0.01\end{array}$ & $\begin{array}{r}6 \\
0.03\end{array}$ & $\begin{array}{r}0 \\
0.00\end{array}$ & $\begin{array}{r}0 \\
0.00\end{array}$ & $\begin{array}{r}0 \\
0.00\end{array}$ & $\begin{array}{r}0 \\
0.00\end{array}$ & $\begin{array}{r}5104 \\
22.68\end{array}$ \\
\hline Uninsured & $\begin{array}{r}4185 \\
18.60\end{array}$ & $\begin{array}{r}1868 \\
8.30\end{array}$ & $\begin{array}{r}1214 \\
5.40\end{array}$ & $\begin{array}{r}717 \\
3.19\end{array}$ & $\begin{array}{r}458 \\
2.04\end{array}$ & $\begin{array}{r}323 \\
1.44\end{array}$ & $\begin{array}{r}215 \\
0.96\end{array}$ & $\begin{array}{r}131 \\
0.58\end{array}$ & $\begin{array}{r}79 \\
0.35\end{array}$ & $\begin{array}{r}47 \\
0.21\end{array}$ & $\begin{array}{r}24 \\
0.11\end{array}$ & $\begin{array}{r}8 \\
0.04\end{array}$ & $\begin{array}{r}10 \\
0.04\end{array}$ & $\begin{array}{r}3 \\
0.01\end{array}$ & $\begin{array}{r}4 \\
0.02\end{array}$ & $\begin{array}{r}2 \\
0.01\end{array}$ & $\begin{array}{r}1 \\
0.00\end{array}$ & $\begin{array}{r}9289 \\
41.28\end{array}$ \\
\hline Total & $\begin{array}{r}10099 \\
44.88\end{array}$ & $\begin{array}{r}4273 \\
18.99\end{array}$ & $\begin{array}{r}2816 \\
12.52\end{array}$ & $\begin{array}{r}1749 \\
7.77\end{array}$ & $\begin{array}{r}1168 \\
5.19\end{array}$ & $\begin{array}{r}842 \\
3.74\end{array}$ & $\begin{array}{r}570 \\
2.53\end{array}$ & $\begin{array}{c}374 \\
1.66\end{array}$ & $\begin{array}{r}241 \\
1.07\end{array}$ & $\begin{array}{r}204 \\
0.91\end{array}$ & $\begin{array}{r}84 \\
0.37\end{array}$ & $\begin{array}{r}35 \\
0.16\end{array}$ & $\begin{array}{r}22 \\
0.10\end{array}$ & $\begin{array}{r}11 \\
0.05\end{array}$ & $\begin{array}{r}7 \\
0.03\end{array}$ & $\begin{array}{r}4 \\
0.02\end{array}$ & $\begin{array}{r}1 \\
0.00\end{array}$ & $\begin{array}{r}22500 \\
100.00\end{array}$ \\
\hline
\end{tabular}


Table 9

Summary of screen numbers vs. pathology code

\begin{tabular}{|c|c|c|c|c|c|c|c|c|c|c|c|c|c|c|c|c|c|c|}
\hline \multicolumn{19}{|c|}{$\mathrm{N}$ (screen times) } \\
\hline \multicolumn{19}{|c|}{ Pathology code } \\
\hline & 1 & 2 & 3 & 4 & 5 & 6 & 7 & 8 & 9 & 10 & 11 & 12 & 13 & 14 & 15 & 16 & 17 & Total \\
\hline 0 & $\begin{array}{l}10082 \\
44.81 \\
\end{array}$ & $\begin{array}{l}4200 \\
18.67 \\
\end{array}$ & $\begin{array}{l}2669 \\
11.86 \\
\end{array}$ & $\begin{array}{l}1585 \\
7.04 \\
\end{array}$ & $\begin{array}{r}1061 \\
4.72 \\
\end{array}$ & $\begin{array}{r}766 \\
3.40 \\
\end{array}$ & $\begin{array}{l}504 \\
2.24 \\
\end{array}$ & $\begin{array}{l}335 \\
1.49 \\
\end{array}$ & $\begin{array}{l}215 \\
0.96 \\
\end{array}$ & $\begin{array}{l}179 \\
0.80 \\
\end{array}$ & \begin{tabular}{|l|}
64 \\
0.28 \\
\end{tabular} & $\begin{array}{l}26 \\
0.12 \\
\end{array}$ & $\begin{array}{l}14 \\
0.06 \\
\end{array}$ & $\begin{array}{l}8 \\
0.04 \\
\end{array}$ & $\begin{array}{l}4 \\
0.02 \\
\end{array}$ & $\begin{array}{l}1 \\
0.00 \\
\end{array}$ & $\begin{array}{l}0 \\
0.00 \\
\end{array}$ & $\begin{array}{r}21713 \\
96.50 \\
\end{array}$ \\
\hline 1 & $\begin{array}{l}11 \\
0.05 \\
\end{array}$ & $\begin{array}{l}42 \\
0.19 \\
\end{array}$ & $\begin{array}{l}87 \\
0.39 \\
\end{array}$ & $\begin{array}{l}79 \\
0.35 \\
\end{array}$ & \begin{tabular}{|l}
57 \\
0.25 \\
\end{tabular} & $\begin{array}{l}41 \\
0.18 \\
\end{array}$ & $\begin{array}{l}28 \\
0.12 \\
\end{array}$ & $\begin{array}{l}24 \\
0.11 \\
\end{array}$ & $\begin{array}{l}12 \\
0.05 \\
\end{array}$ & $\begin{array}{l}13 \\
0.06 \\
\end{array}$ & \begin{tabular}{|l|}
10 \\
0.04 \\
\end{tabular} & $\begin{array}{l}1 \\
0.00 \\
\end{array}$ & $\begin{array}{l}4 \\
0.02 \\
\end{array}$ & $\begin{array}{l}1 \\
0.00 \\
\end{array}$ & $\begin{array}{l}1 \\
0.00 \\
\end{array}$ & \begin{tabular}{|l}
1 \\
0.00 \\
\end{tabular} & $\begin{array}{l}0 \\
0.00 \\
\end{array}$ & $\begin{array}{l}412 \\
1.83 \\
\end{array}$ \\
\hline 2 & \begin{tabular}{|l}
2 \\
0.01 \\
\end{tabular} & $\begin{array}{l}6 \\
0.03 \\
\end{array}$ & $\begin{array}{l}15 \\
0.07 \\
\end{array}$ & $\begin{array}{l}28 \\
0.12 \\
\end{array}$ & \begin{tabular}{|l|}
16 \\
0.07 \\
\end{tabular} & $\begin{array}{l}12 \\
0.05 \\
\end{array}$ & $\begin{array}{l}16 \\
0.07 \\
\end{array}$ & $\begin{array}{l}7 \\
0.03 \\
\end{array}$ & $\begin{array}{l}9 \\
0.04 \\
\end{array}$ & $\begin{array}{l}6 \\
0.03 \\
\end{array}$ & $\begin{array}{l}5 \\
0.02 \\
\end{array}$ & $\begin{array}{l}6 \\
0.03 \\
\end{array}$ & $\begin{array}{l}4 \\
0.02 \\
\end{array}$ & $\begin{array}{l}1 \\
0.00 \\
\end{array}$ & $\begin{array}{l}1 \\
0.00 \\
\end{array}$ & \begin{tabular}{|l}
1 \\
0.00 \\
\end{tabular} & $\begin{array}{l}1 \\
0.00 \\
\end{array}$ & $\begin{array}{l}136 \\
0.60 \\
\end{array}$ \\
\hline 3 & \begin{tabular}{|l}
0 \\
0.00 \\
\end{tabular} & $\begin{array}{l}0 \\
0.00 \\
\end{array}$ & $\begin{array}{l}0 \\
0.00 \\
\end{array}$ & $\begin{array}{l}1 \\
0.00 \\
\end{array}$ & $\begin{array}{l}0 \\
0.00 \\
\end{array}$ & $\begin{array}{l}2 \\
0.01 \\
\end{array}$ & $\begin{array}{l}1 \\
0.00 \\
\end{array}$ & $\begin{array}{l}1 \\
0.00 \\
\end{array}$ & $\begin{array}{l}0 \\
0.00 \\
\end{array}$ & $\begin{array}{l}1 \\
0.00 \\
\end{array}$ & $\begin{array}{l}0 \\
0.00 \\
\end{array}$ & $\begin{array}{l}0 \\
0.00 \\
\end{array}$ & $\begin{array}{l}0 \\
0.00 \\
\end{array}$ & $\begin{array}{l}0 \\
0.00 \\
\end{array}$ & $\begin{array}{l}0 \\
0.00 \\
\end{array}$ & \begin{tabular}{|l}
0 \\
0.00 \\
\end{tabular} & $\begin{array}{l}0 \\
0.00 \\
\end{array}$ & $\begin{array}{l}6 \\
0.03 \\
\end{array}$ \\
\hline 4 & $\begin{array}{l}0 \\
0.00 \\
\end{array}$ & $\begin{array}{l}2 \\
0.01 \\
\end{array}$ & $\begin{array}{l}7 \\
0.03 \\
\end{array}$ & $\begin{array}{l}7 \\
0.03 \\
\end{array}$ & $\begin{array}{l}4 \\
0.02 \\
\end{array}$ & $\begin{array}{l}4 \\
0.02 \\
\end{array}$ & $\begin{array}{l}3 \\
0.01 \\
\end{array}$ & $\begin{array}{l}0 \\
0.00 \\
\end{array}$ & $\begin{array}{l}1 \\
0.00 \\
\end{array}$ & $\begin{array}{l}1 \\
0.00 \\
\end{array}$ & $\begin{array}{l}1 \\
0.00 \\
\end{array}$ & $\begin{array}{l}1 \\
0.00 \\
\end{array}$ & $\begin{array}{l}0 \\
0.00 \\
\end{array}$ & $\begin{array}{l}0 \\
0.00 \\
\end{array}$ & $\begin{array}{l}0 \\
0.00 \\
\end{array}$ & \begin{tabular}{|l}
0 \\
0.00 \\
\end{tabular} & $\begin{array}{l}0 \\
0.00 \\
\end{array}$ & $\begin{array}{l}31 \\
0.14 \\
\end{array}$ \\
\hline 5 & $\begin{array}{l}0 \\
0.00 \\
\end{array}$ & $\begin{array}{l}1 \\
0.00 \\
\end{array}$ & $\begin{array}{l}0 \\
0.00 \\
\end{array}$ & $\begin{array}{l}1 \\
0.00 \\
\end{array}$ & $\begin{array}{l}0 \\
0.00 \\
\end{array}$ & $\begin{array}{l}1 \\
0.00\end{array}$ & $\begin{array}{l}0 \\
0.00 \\
\end{array}$ & $\begin{array}{l}0 \\
0.00 \\
\end{array}$ & $\begin{array}{l}0 \\
0.00 \\
\end{array}$ & $\begin{array}{l}0 \\
0.00 \\
\end{array}$ & $\begin{array}{l}0 \\
0.00 \\
\end{array}$ & $\begin{array}{l}0 \\
0.00 \\
\end{array}$ & $\begin{array}{l}0 \\
0.00 \\
\end{array}$ & $\begin{array}{l}0 \\
0.00 \\
\end{array}$ & $\begin{array}{l}0 \\
0.00 \\
\end{array}$ & \begin{tabular}{|l}
0 \\
0.00 \\
\end{tabular} & $\begin{array}{l}0 \\
0.00 \\
\end{array}$ & $\begin{array}{l}3 \\
0.01 \\
\end{array}$ \\
\hline 6 & $\begin{array}{l}4 \\
0.02 \\
\end{array}$ & $\begin{array}{l}22 \\
0.10 \\
\end{array}$ & $\begin{array}{l}38 \\
0.17 \\
\end{array}$ & $\begin{array}{l}48 \\
0.21 \\
\end{array}$ & $\begin{array}{l}30 \\
0.13 \\
\end{array}$ & $\begin{array}{l}16 \\
0.07\end{array}$ & $\begin{array}{l}18 \\
0.08 \\
\end{array}$ & $\begin{array}{l}7 \\
0.03 \\
\end{array}$ & $\begin{array}{l}4 \\
0.02 \\
\end{array}$ & $\begin{array}{l}4 \\
0.02 \\
\end{array}$ & $\begin{array}{l}4 \\
0.02 \\
\end{array}$ & $\begin{array}{l}1 \\
0.00\end{array}$ & $\begin{array}{l}0 \\
0.00 \\
\end{array}$ & $\begin{array}{l}1 \\
0.00\end{array}$ & $\begin{array}{l}1 \\
0.00 \\
\end{array}$ & $\begin{array}{l}1 \\
0.00 \\
\end{array}$ & $\begin{array}{l}0 \\
0.00 \\
\end{array}$ & $\begin{array}{l}199 \\
0.88 \\
\end{array}$ \\
\hline Total & $\begin{array}{l}10099 \\
44.88\end{array}$ & $\begin{array}{l}4273 \\
18.99\end{array}$ & $\begin{array}{l}2816 \\
12.52\end{array}$ & $\begin{array}{l}1749 \\
7.77\end{array}$ & $\begin{array}{l}1168 \\
5.19\end{array}$ & $\begin{array}{l}842 \\
3.74\end{array}$ & $\begin{array}{l}570 \\
2.53\end{array}$ & $\begin{array}{l}374 \\
1.66\end{array}$ & $\begin{array}{l}241 \\
1.07\end{array}$ & $\begin{array}{l}204 \\
0.91\end{array}$ & $\begin{array}{l}84 \\
0.37\end{array}$ & $\begin{array}{l}35 \\
0.16\end{array}$ & $\begin{array}{l}22 \\
0.10\end{array}$ & $\begin{array}{l}11 \\
0.05\end{array}$ & $\begin{array}{l}7 \\
0.03\end{array}$ & $\begin{array}{l}4 \\
0.02\end{array}$ & $\begin{array}{l}1 \\
0.00\end{array}$ & $\begin{array}{l}22500 \\
100.00\end{array}$ \\
\hline
\end{tabular}




\section{CHAPTER IV}

\section{CONCLUSION}

This de-identified breast cancer screen data set includes the information of 22534 women and 58231 screens from 2001-2010. Two parts of analysis have been done with this data. At first, the trend and disparities in the diagnosis of breast cancer by mobile mammography between age, race, insurance system and screen location over the years based on screen number are analyzed. After removing 10 missing or bad data, there are 58221 screens for analysis. We found: (1) For age group, women younger than 50 are more likely to take the screen and comprise $40 \%$ of the screens, aged group from $50-59$ is the next and comprise $32.75 \%$ of the screen, then followed by age group $60-69(17.70 \%)$, women older than 70 years is the least $(9.86 \%)$. (2) For race, $64 \%$ of screens are taken by white, $30 \%$ by black, and only $8 \%$ by the others. (3) For insurance system, it is surprised that the women without insurance take $40 \%$ of screens, then the private insured women which is $36 \%$, public insured women contribute only $24 \%$. (4) For location, people are more likely to go to partnership clinic $(43.49 \%)$, then corporate $(33.23 \%)$. The last one is partnership community (23.29\%). The year of 2006 has the highest number of screens which is 6861 and 2001 has the lowest number of 4813 . Over the years, the trend of age group for three different races are similar, the older the age, the less the screen frequency (Figures 1-3); the pattern of age group for three different insurance system are not the same. The pattern of "public insured" is opposite to "Private insured" and 
"Uninsured". The reason partially is that "Public insured" (medicare and medicaid) aralways issued to old women (Figures 4-6); All three different locations "corporate", "partnership clinic", and "partnership community" have similar trends for all age groups over the 10 years. As shown in Figures 7-9, except few cases, it generally follows the rule: the older, the fewer screens. The disparities of pathology results of screens based on different insurance system, age groups, and races have also been analyzed in this study (Table 3). For code =0, age group " $50-"$, race = "white", and Insured = "uninsured" have the highest percent numbers, $39.63 \%, 63.92 \%$ and $39.25 \%$, respectively under each categorical variable; For code $=6$, age group " $50-59$ ", race $=$ "white", and Insured $=$ "uninsured" have the highest \% like, 35.19\%, 59.66\% and 48.07\%. Besides, Chi-square tests were performed to test the association. For all three categorical variables, $\mathrm{P}$ values are less than 0.001 , which provide strong evidence of an association between "code (pathology code)" and all other three categorical variables "agegroup", "race", and "Insured". The trend studies are to check the patterns between race/insurance system of all age groups for each specific pathology code (Figures 10-13).

As mentioned before, there are 22534 individuals participant the program, the odds ratio analysis is done on white and black women only because they are the majority of participants (90\%). some women have multiple screens with multiple pathology codes. For each woman, only the case with maximum pathology code was chosen for odds ratio calculation. There are 20342 women left for analysis. The calculated odds ratios and their $95 \%$ confidence intervals are present in Tables 5-7. Basically, for race/insurance, in age groups " $50-$ ", " $50-59$ "'and ' $70+$ ', the odds of white people with insurance is $1.7,1.9$, and 0.4 times of black people with insurance respectively. No much difference in odds 
was found in age group "60-69". For race/pathology_result, the significant result is only for age group "70+", the odds of white women with "Negative" pathology result is 4.4 times of black women with "Negative" pathology result. Besides, for insurance/pathology result, the odds of women with insurance "Yes" having "Negative" pathology result are 2.26 and 2.08 times of the women with insurance "Yes" having "Negative" pathology result for age group "50-" and "50-59". The follow-up study was performed based on 22500 women ( 34 of 22534 with missing information). The maximum number that each person took the screen for this data set is 17 . The majority (45\%) only take screen once. About $19 \%$ of women took twice, $12 \%$ took triple. Only one woman took 17 times. Pearson and Spearman correlation coefficients were calculated to check the association. Table 10 is the stratified levels of all participants (20342 women including white and black only). 
Table 10

Race/insurance to pathology result for different age group

\begin{tabular}{|c|c|c|c|c|c|}
\hline \multirow{2}{*}{$\begin{array}{l}\text { Age } \\
\text { group }\end{array}$} & \multirow[b]{2}{*}{ Race } & \multirow{2}{*}{$\begin{array}{l}\text { Insurance } \\
\text { (Yes="Public Insured" or } \\
\text { "Private Insured"; } \mathrm{No}^{-} \\
\text {"Uninsured") }\end{array}$} & \multicolumn{2}{|c|}{ Pathology Result } & \multirow[b]{2}{*}{$\begin{array}{l}\text { Odds } \\
\text { Ratio }\end{array}$} \\
\hline & & & $\begin{array}{c}\text { Positive } \\
(\text { code }=0-3)\end{array}$ & $\begin{array}{l}\text { Negative } \\
(\text { code }=4-6)\end{array}$ & \\
\hline \multirow[t]{4}{*}{ 50- } & \multirow[t]{2}{*}{ White } & Yes & 15 & 3395 & \multirow[t]{2}{*}{0.45} \\
\hline & & No & 25 & 2559 & \\
\hline & \multirow{2}{*}{ Black } & Yes & 4 & 1195 & \multirow{2}{*}{0.39} \\
\hline & & No & 13 & 1503 & \\
\hline \multirow[t]{4}{*}{$50-59$} & \multirow[t]{2}{*}{ White } & Yes & 22 & 2739 & \multirow[t]{2}{*}{0.50} \\
\hline & & No & 28 & 1726 & \\
\hline & \multirow[t]{2}{*}{ Black } & Yes & 8 & 893 & \multirow[t]{2}{*}{0.47} \\
\hline & & No & 18 & 952 & \\
\hline \multirow[t]{4}{*}{$60-69$} & \multirow[t]{2}{*}{ White } & Yes & 21 & 1561 & \multirow[t]{2}{*}{0.79} \\
\hline & & No & 12 & 701 & \\
\hline & \multirow[t]{2}{*}{ Black } & Yes & 10 & 618 & \multirow[t]{2}{*}{0.63} \\
\hline & & No & 7 & 273 & \\
\hline \multirow[t]{4}{*}{$70+$} & \multirow[t]{2}{*}{ White } & Yes & 12 & 1476 & \multirow[t]{2}{*}{0.18} \\
\hline & & No & 2 & 45 & \\
\hline & \multirow[t]{2}{*}{ Black } & Yes & 20 & 483 & \multirow[t]{2}{*}{ \#DIV/0! } \\
\hline & & No & 0 & 6 & \\
\hline
\end{tabular}




\section{REFERENCES}

http://www.cancer.org/Cancer/BreastCancer/DetailedGuide/breast-cancerkey-statistics

Elmore JG, Armstrong K, Lehman CD, Fletcher SW. Screening for breast cancer. JAMA 2005;293(10): 1245-1256.

Althuis MD, Dozier JM, Anderson WF, Devesa SS, Brinton LA (2005) Global trends in breast cancer incidence and mortality 1973-1997. Int J Epi 34:405-412

Australian Institute of Health and Welfare (2003) Breast Screen Australia Monitoring Reports 1998-99, 1999-2000 and 2000-2001. Cancer series numbers 25 and 26; AIHW Cat.Nos. CAN 20 and CAN 21. Canberra, AIHW

http://www.cdc.gov/nchs/healthy_people/hp2010/hp2010_final_review.htm

Feldstein AC, Vogt TM, Aickin M, Hu WR. Mammography screening rates decline: A person-time approach to evaluation. Prev Med 2006; 43(3): 178-182.

Burns RB, McCarthy EP, Freund KM, Marwill SL, Shwartz M, Ash A, et al. Black women receive less mammography even with similar use of primary care. Ann Intern Med 1996; 125(3): 173-182.

Makuc DM, Breen N, Freid V. Low income, race, and the use of Mammography; Health Serv Res 1999; 34(1 Pt 2): 229-239.

Schootman M, Jeffe DB, Reschke AH, Aft RL. Disparities related to socioeconomic status and access to medical care remain in the United States among women who never had a mammogram. Cancer Causes Control 2003;14(5): 419-425.

Bigby J, Holmes MD. Disparities across the breast cancer continuum Cancer Causes Control 2005; 16(1): 35-44.

Kim J, Jang SN, Socioeconomic Disparities in Breast Cancer Screening 
among US Women: Trends from 2000 to $2005, J$ Prev Med Public Health 2008;41(3):186-194

Autier P, Boniol M, LaVecchia C, Vatten L, Gavin A, He'ry C, Heanue M, Disparities in breast cancer mortality trends between 30 European countries: retrospective trend analysis of WHO mortality database , BMJ 2010;341:c3620 doi:10.1136/bmj.c3620

Peek ME, Han JH.Disparities in screening mammography. Current status, interventions and implications. J Gen Intern Med. 2004 Feb;19(2):184-94.

Anonymous. Self-reported use of mammography and insurance status among women aged greater than or equal to 40 years-United States, 199192 and 1996-97. Morb Mortal Wkly Rep. 1998;47:825-30.

Robert Wood Johnson Foundation Special Report. Access to health care in the United States: results of a 1986 survey. 1987;2:1-11.

Katz SJ, Hofer TP. Socioeconomic disparities in preventive care persist despite universal coverage: breast and cervical cancer screening in Ontario and the United States. JAMA. 1994;272:530-4.

Swan J, Breen N, Coates RJ, Rimer BK, Lee NC. Progress in cancer screening practices in the United States. Results from the 2000 National Health Interview Study. Cancer. 2003;97:1528-40.

McCarthy EP, Burns RB, Coughlin SS, Freund KM, Rice J, Marwill SL, Shwartz M, Moskowitz MA; Mammography use helps to explain differences in breast cancer stage at diagnosis between older black and white women.. Ann Intern Med. 1998 May 1;128(9):729-36.

Anderson LM, May DS. Has the use of cervical, breast, and colorectal cancer screening increased in the United States? Am J Public Health. 1995; $85: 840-2$.

Breen N, Kessler L. Changes in the use of screening mammography: evidence from the 1987 and 1990 National Health Interview Surveys. Am J Public Health. 1994;84:62-7.

The NCI Breast Cancer Screening Consortium. Screening mammography: a missed clinical opportunity? Results of the NCI Breast Cancer Screening Consortium and National Health Interview Survey Studies. JAMA. 1990;264: 54-8. 
Kosary CL, Ries LAG, Miller BA, et al, eds. SEER Cancer Statistics Review 1973-1992: Tables and Graphs. Bethesda, Md: National Institute of Health, Publication No 96-2789; 1995.

Morris CR, Wright WE, eds. Breast Cancer in California. Sacramento, Calif: California Department of Health Services, Cancer Surveillance Section; 1996.

Smith-Bindman R, Kerlikowske K, Gebretsadik T, Newman J. Is screening mammography effective in elderly women? Am J Med. 2000;108:112-9.

Randolph WM, Goodwin JS, Mahnken JD, Freeman JL. Regular mammography use is associated with elimination of age-related disparities in size and stage of breast cancer at diagnosis. Ann Intern Med. 2002;137:783-90.

Satariano WA, Ragland DR. The effect of comorbidity on 3-year survival of women with primary breast cancer. Ann Intern Med. 1994;120:10410.

American Medical Association Council on Scientific Affairs. Mammographic screening in asymptomatic women aged 40 years and older. JAMA. 1989;262:2535-2542.

US Preventive Services Task Force. Guide to Clinical Preventive Services. Alexandria, Va: International Medical Publishing; 1996.

Leitch AM. Controversies in breast cancer screening. Cancer. 1995; 76 (suppl 10):2064-2069.

Leitch AM, Dodd GD, Costanza M, et al. American Cancer Society guidelines for the early detection of breast cancer: update 1997. CA Cancer $J$ Clin. 1997; 47:150-153.

Screening recommendations of the forum panel. J Gerontol 1992; :5.

Blackman DK, Bennett EM, Miller DS. Trends in self-reported use of mammograms (1989-97) and papanicolaou tests 1991-97Behavioral Risk Factor Surveillance System. Morb Mortal Wkly Rep. 1999;48:1-22.

Smith RA, D’Orsi CJ. Broast imaging and image-guided biopsy techniques. In: Harris JR, ed. Screening for Breast Cancer. Diseases of the Breast, 2nd edn. Philadelphia, Pa: Lippincott Williams \& Wilkins; 2000. 
Carr WP, Maldonado G, Leonard PR, et al. Mammogram utilization among farm women. $J$ Rural Health. 1996;12:278-290.

O'Malley MS, Earp JAL, Harris RP. Race and mammography use in two North Carolina counties. Am J Public Health. 1997;87:782-786.

Flynn BS, Gavin P, Worden JK, Ashikaga T, Gautam S, Carpenter J. Community education programs to promote mammography participation in rural New York State. Prev Med. 1997;26:102-108.

Liff JM, Chow WH, Greenberg RS. Rural-urban differences in stage at diagnosis. Cancer. 1991;67:1454-1459.

Coughlin SS, Thompson TD, Hall HI, Logan P, Uhler RJ. Breast and cervical carcinoma screening practices among women in rural and nonrural areas of the United States, 1998-99. Cancer. 2002;94:2801-12.

Kreher NE, Hinkner JM, Rufin MT, Lin CH. Effect of distance and travel time on rural women's compliance with screening mammography: the UPRNet study. J Fam Pract. 1995;40:143-7.

Hall HI, Uhler RJ, Coughlin SS, Miller DS. Breast and cervical cancer Screening among Appalachian women. Cancer Epidemiol Biomarkers Prev. 2002;11:137-42. 


\section{CURRICULUM VITAE}

NAME:

ADDRESS:

EDUCATION

\& TRAINING:

Dianhong Luo

7014 wooded meadow road, Louisville, KY 40241

PhD., Material Science and Engineering

New Jersey Institute of Technology

$1998-2001$

EMPLOYMENT: University of Louisville

Louisville, KY, 2009-present

Peptides International, Louisville

KY 2008 - 2009

Yale University

New Haven, CT, 2003-2008

Qusion Technologies Inc., North Brunswick, NJ, 2001-2002

PUBLICATION: $\quad$ Conducted the study of evaluating the long-term effect of Fecal Occult Blood Test (FOBT) in colorectal cancer screening

Cancer Epidemiology (2011)

doi:10.1016/j.canep.2011.09.011 